\title{
SHOULD PRIVATE EXPECTATIONS CONCERN CENTRAL BANKERS?
}

\author{
Martin Fukač
}
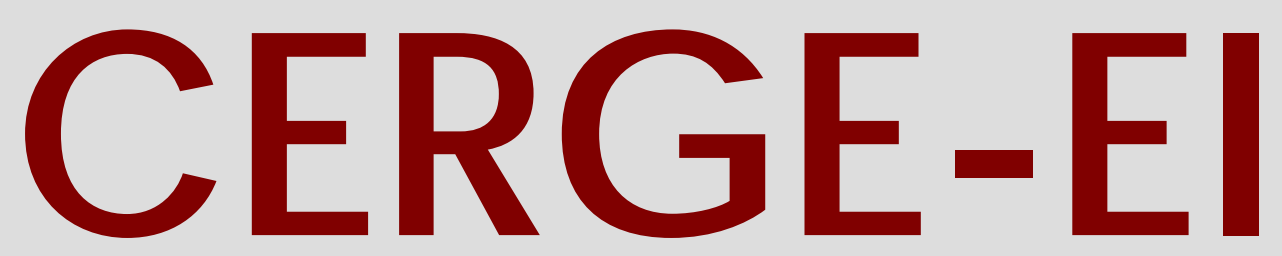

Charles University Centerfor Economic Research and Graduate Education Academy of Sciences of the Czech Republic Ec onomic s Institute 


\title{
Working Paper Series (ISSN 1211-3298)
}

\section{Should Private Expectations Concern Central Bankers?}

\author{
Martin Fukač
}

CERGE-EI

Prague, October 2005 
ISBN 80-7343-071-1 (Univerzita Karlova v Praze, CERGE)

ISBN 80-7344-060-1 (Národohospodářský ústav AV ČR, Praha) 


\title{
Should Private Expectations Concern Central Bankers?
}

\author{
Martin Fukač* \\ CERGE-EI**
}

October 2005

\begin{abstract}
We analyze the standard New Keynesian economy adjusted by a financial intermediation sector, heterogenous, imperfect knowledge, and adaptive learning. We consider two groups of agents (i) private agents (households, firms, private banks) and (ii) the central bank who differ in their knowledge and expectations. The monetary-policy transmission is non-trivial in this environment. The interest rate directly affecting the decisions of households and firms is influenced by the private banks expectations, and the monetary policy may get distorted. The basic finding suggests the higher knowledge heterogeneity, the less active monetary policy should be in order to stabilize the economy. This contrasts the standard literature with homogenous knowledge and expectations.
\end{abstract}

\begin{abstract}
Abstrakt
V tomto článku zkoumáme ekonomickou dynamiku v kontextu nového keynesiánského modelu rozširreného o finanční sektor, heterogenní, nedokonalou informaci a adaptivní učení. Rozlišujeme dvě skupiny ekonomických agentů: (i) soukromé agenty (domácnosti, firmy a soukromé banky) a (ii) centrální banku. U obou skupin předpokládáme odlišné znalosti a očekávání. $V$ tomto prostředí už to není centrální banka, která má přímý vliv na ekonomiku, ale jsou to soukromé banky. Jejich úrokové sazby nyní vstupují do rozhodování domácností a firem. Transmise monetární politiky se tak stává netriviální. Původní záměr centrální banky, např. cílovat inflaci, může být vychýlen sazbami soukromých bank, které je stanovují na základě vlastní informace a očekávání. V analýze docházíme $\mathrm{k}$ závěru, který je $\mathrm{v}$ kontrastu s literaturou pracující s homogenní, nedokonalou informací. Čím větší je rozdíl znalostí mezi oběma skupinami agentů, tím méně by měla monetarní politika být aktivní. Snižuje se tak variabilita ekonomických veličin a zrychluje se konvergence do ekonomické rovnováhy při dokonalé informaci.
\end{abstract}

Keywords: imperfect and heterogeneous knowledge, adaptive learning, monetary

policy

JEL classification: E52

The author would like to thank Michal Kejak, Sergey Slobodyan, Kristoffer Nimark, and the participants of CFS Summer School 2005 for their helpful comments and suggestions. The author would also like to thank Robin-Eliece Mercury for her editing assistance. The usual disclaimer applies.

*Email: martin.fukac@cerge-ei.cz

**A joint workplace of the Center for Economic Research and Graduate Education, Charles University, Prague, and the Economics Institute of the Academy of Sciences of the Czech Republic.

Address: CERGE-EI, P.O. Box 882, Politických veznu 7, Prague 1, 111 21, Czech Republic 


\section{Introduction}

The paper's objective is to theoretically investigate the question of whether central bankers should consider private expectations when setting monetarypolicy instruments. If they do so, will it lead to an increase in economic stability?

Since private expectations may distort monetary policy actions, we analyze the question of whether private expectations should affect monetary policy decisions. In standard models, the homogeneity of expectations is assumed, i.e., the private sector and central bank have the same knowledge about the economy structure and form the same expectations. Here the assumption is weakened. We distinguish between expectations formed by the private sector (here households, firms, and banks) and by the central bank. Further, the private and central bank's imperfect and heterogenous knowledge is adaptively updated.

The analysis is conducted in a dynamic general equilibrium model of the New Keynesian form which allows for a banking sector. The banking sector plays an important role in the policy transmission mechanism here.

The main contribution of this paper is the analysis of monetary policy in a heterogenous knowledge environment. In the standard model set-up, the economy wide interest rate is predetermined by the central bank. It is predetermined in the sense that it does not bring any uncertainty to private sector decisions. In our model, the interest rate relevant for the inflation and output gap dynamics is determined by the banking sector. The monetary policy still has a stabilizing role, but now it also depends on the banking sector's objectives and beliefs when 
determining interest rates. This makes the policy transmission mechanism nontrivial, and, if the central bank does not know the transmission mechanism, it may cause policy inefficiency and possibly economic instability.

In the environment outlined above we address the following questions:

\section{Should private forecasts concern policy makers?}

Given the heterogeneity of expectations in the model, should private expectations enter the policy rule or should the policy rule be based primarily on the central bank's beliefs? What are the implications for economic stability?

2. In the heterogenous knowledge environment, should the central bank be more inflation averse or output gap averse?

Orphanides \& Williams (2003) and Ferrero (2003) tend to favor inflation vigilance. It lowers economic variability and speeds up the convergence towards the rational expectations equilibrium. Both results are, however, derived for the homogenous expectations case. We reinvestigate this problem in a richer model and under heterogenous expectations.

3. Does it matter who has better knowledge? On one hand, there are central banks employing sophisticated techniques to analyze the economy and to forecast a possible future development. On the other hand, there are private agents using less sophisticated techniques to produce their own forecasts. We analyze the situation in which a central bank ignores private forecasts and bases its policy primarily on its own forecasts. We asses the impact on the economic variability from the perspective of a knowledge imperfection, eg. is the economy less volatile if the central bank has 'better' knowledge than private agents? The concept of knowledge in this paper is defined below.

A New Keynesian model is the typical environment for studying policy issues under learning. In this paper, we derive from first principles a new model which 
also explicitly includes a banking sector. Extending the standard model structure for a credit channel yields a direct impact of monetary policy on inflation. Since, firms borrow money from banks, the interest paid for the credit becomes the part of firms' costs and because the firms have the power to set their output prices, the interest rate influences prices and inflation. This does not occur in the standard setup. The introduction of the banking sector is originally motivated by Fuerst (1992). Ravenna \& Walsh (2003) use his approach in the context of the New Keynesian model.

For simulation purposes, the perpetual learning concept as employed in Orphanides \& Williams (2003), will be adopted here. The paper by Orphanides \& Williams (2003) is one of the first that investigates the impact of imperfect knowledge and perpetual adaptive learning on macroeconomic dynamics and the conduct of optimal monetary policy. The authors find two basic results: (i) "policies that would be efficient under rational expectations can perform poorly when knowledge is imperfect", Orphanides and Williams (2003, p.26), and (ii) "policy should respond more aggressively to inflation under imperfect knowledge than under perfect knowledge... in order to anchor inflation expectations and foster macroeconomic stability", Orphanides and Williams (2003, p.26).

The results are obtained with a very basic model consisting of the Lucas supply curve and a simple inflation targeting rule. In the light of the simplicity of the model, Evans (2003) answers the second result above in doubt. For him, there is no clear answer whether the policy maker should be biased towards inflation vigilance under imperfect knowledge. However though the answer might be ambiguous, it has not yet been provided, and we try to provide it here.

Evans \& Honkapohja (2003) provide a review and extension of the recent work on monetary policy under learning. They also investigate, among other items, the consequences of different beliefs between private agents and policy-makers about 
the true economy structure. They show that certain policy rules allow for Estability and determinacy, even if the beliefs of private agents and the central bank differ. E-stability and determinacy also exist if the cental bank adopts the private agents' beliefs when setting its instruments. The same result is found in Bullard \& Mitra (2002).

The authors use the concept of (finite-horizon) Euler-equation learning. Preston (2004) has addressed the problem from the perspective of infinite learning and produced different results. In Preston's approach, if both agents and policy-makers are learning about the model structure, and the central bank adopts the private agents expectations for its decisions without how they are formed, than it may result in a self-fulfilling expectation problem and macroeconomic instability. Preston argues in favor of policy rules based on the bank's own forecasts.

Honkapohja, Mitra \& Evans (2003) show that the approach of infinite learning in Preston (2004) does not invalidate results based on the Euler equation learning and demonstrate that Preston's approach can be replicated under plausible assumptions in the Euler-equation learning approach. In this paper we adopt the latter.

The rest of this paper is structured in the following way. In the next section, a general equilibrium model with a financial intermediation sector and a sticky prices phenomenon is derived. The model dynamics is aggregated and represented by the IS and the New Keynesian Phillips curve. In section 3, we introduce the concept of imperfect and heterogenous knowledge, and the model determinacy and E-stability properties are examined. We simulate the model for different numerical specifications and present the results in section 4 . Section 5 summarizes the findings and concludes. 


\section{The Model}

The workhorse model follows the standard New Keynesian DSGE schema. On the one hand, there are households who make decisions about consumption, labour, and money holdings in order to maximize and smooth their lifetime welfare. On the other hand, there is a monopolistically competitive production sector that maximizes profits by controlling output, output prices and labour demand. The central bank's objective is characterized by a forward-looking inflation targeting rule which seeks to anchor the nominal side of the economy.

Borrowing from the RBC literature, we extend otherwise the purely New Keynesian model by the sector of financial intermediation. Following Fuerst (1992), we introduce a financial sector with two frictions. First, all purchases (labour, consumption goods) have to be paid by cash. Second, decisions about cash-money holdings are made prior to an exogenous shocks realization. In the RBC literature such a financial structure helps an RBC model to capture the liquidity effect observed in the data. To make the liquidity effect persistent though, an additional friction has to be introduced. Christiano \& Eichenbaum (1992) and Gust \& Christiano (1999) generate the persistent liquidity effect by making the financial sector more liquid than the consumption sector, imposing costs on household's financial portfolio adjustments.

We introduce the credit sector to the New Keynesian set-up to make the model structure more plausible. The standard New Keynesian model usually omits financial intermediation which in reality plays a considerable role in monetary transmission. This is not an original idea. Ravenna \& Walsh (2003) analyzed optimal monetary policy in such a model. We use the same model to analyze its properties under imperfect, heterogenous knowledge and adaptive learning.

The linearized model characterizing the aggregate economic dynamics is given by the IS curve (1), Phillips curve (2), private banks' pricing rules (3), (4), and 
the central bank's policy rule (5). In the perfect-knowledge environment, the aggregated sticky-price model takes the form

$$
\begin{aligned}
x_{t} & =E_{t} x_{t+1}-\sigma\left(i_{t}^{d}-E_{t} \pi_{t+1}\right)+v_{t}, \\
\pi_{t} & =\beta E_{t} \pi_{t+1}+\lambda x_{t}+\gamma i_{t}^{b}+u_{t}, \\
i_{t}^{b} & =i_{t}^{C B} \\
i_{t}^{d} & =E_{t-1} i_{t}^{C B} \\
i_{t}^{C B} & =\theta_{\pi}\left(E_{t} \pi_{t+1}-\pi^{*}\right)+\theta_{x} E_{t} x_{t+1} .
\end{aligned}
$$

The model differs from the standard New Keynesian schema in one aspect. As the firms face the credit-in-advance constraint, the interest rate does have a direct impact on inflation since it is a part of the costs the firm has to pay on labour. It is in contrast to the usual setup where only the IS curve is a function of the interest rate. In this model, due to the cost channel, monetary policy has a direct effect not only on the output gap but also on the inflation rate. The derivation of the model is presented in Appendix A on page 27.

The model (1)-(5) assumes all economic agents have perfect knowledge about the economy structure and all expectations operators $E_{t}()=.E_{t}\left(. \mid \Omega_{t}\right)$ stand for the perfect knowledge rational expectations. In our analysis, the assumption that the complete information set $\Omega_{t}$ is available to all agents is relaxed. Instead, we will assume agents have imperfect and heterogenous knowledge which will affect the way agents form their expectations. We will consider two groups of agents: (i) private agents - households, firms, private banks, and (ii) the central bank. In the following analysis it will be distinguished between the expectation operators which these two groups form. We will assume expectations' homogeneity within each group but heterogeneity between the groups, that is all households, firms and private banks will share the same set of information and beliefs, but, it differs from 
the information set and beliefs of the central bank. This is a significant relaxation of the original, homogenous, perfect knowledge set-up.

Consequently, the workhorse model for this paper takes the form

$$
\begin{aligned}
x_{t} & =\hat{E}_{t}^{P} x_{t+1}-\sigma\left(E_{t-1}^{P} i_{t}^{C B}-\hat{E}_{t}^{P} \pi_{t+1}\right)+v_{t}, \\
\pi_{t} & =\beta \hat{E}_{t}^{P} \pi_{t+1}+\lambda x_{t}+\gamma i_{t}^{C B}+u_{t}, \\
i_{t}^{C B} & =\theta_{\pi}\left(\hat{E}_{t}^{C B} \pi_{t+1}-\pi^{*}\right)+\theta_{x} \hat{E}_{t}^{C B} x_{t+1},
\end{aligned}
$$

where it is specifically distinguished for the form of expectations formed by private

agents, $\hat{E}_{t}^{P}()=.E_{t}\left(. \mid \Omega_{t}^{P}\right)$, and by the central bank $\hat{E}_{t}^{C B}()=.E_{t}\left(. \mid \Omega_{t}^{C B}\right)$, where $\Omega_{t}^{P}, \Omega_{t}^{C B} \subset \Omega_{t}$. Honkapohja et al. (2003) show that the move from the perfect knowledge model to the imperfect and heterogenous knowledge model is possible under the so called Euler-equation learning. If all agents are adaptively learning (using recursive least squares), the originally heterogenous knowledge $\Omega_{t}^{P} \Omega_{t}^{C B}$ enriches over time so that it converges to the perfect knowledge set $\Omega_{t}$.

\section{Model Analysis Under Adaptive Learning}

Besides the imperfect knowledge and heterogeneity between the private agents' and central bank's expectations, we also assume agents are adaptively learning, i.e., they are improving their knowledge about the economy over time, and upon the past mistakes they made in the anticipation of economic movements. Under certain conditions, if all agents are improving their knowledge over time, the economy converges to the perfect knowledge case eventually. In this light the perfect knowledge case, the rational expectations equilibrium (REE), is a special case of an imperfect knowledge environment.

As will be shown below, the minimum-state representation to the structural 
model (6)-(8) is

$$
Y_{t}=a+b s_{t}+c s_{t-1},
$$

where $Y_{t}$ is the vector of endogenous variables, $s_{t}$ is the vector of exogenous shocks, and $\{a, b, c\}$ are the matrices of the structural parameters.

If we say the agents have imperfect and heterogenous knowledge, we assume the agents' perception of the economy does not correspond to the perfect knowledge case and further, the knowledge differs between the agents. It is assumed the private agents' perceived law of motion (PLM) for the economy (6)-(8) takes the form

$$
Y_{t}=\hat{a}_{t}^{P}+\hat{b}_{t}^{P} s_{t}+\hat{c}_{t}^{P} s_{t-1}
$$

and the central bank's MSV is

$$
Y_{t}=\hat{a}_{t}^{C B}+\hat{b}_{t}^{C B} s_{t}+\hat{c}_{t}^{C B} s_{t-1}
$$

where $\left\{\hat{a}_{t}^{i}, \hat{b}_{t}^{i}, \hat{b}_{t}^{i}\right\} \in \Omega_{t}^{i}$ for $i=\{P, C B\}$ are the time-varying matrices of the model primitives. We implicitly assume here, agents have perfect knowledge about the economy structure, i.e., they know what the right-hand side variables are, but they have imperfect knowledge about the true values of model primitives. Though, they are learning about the structural matrices $\{a, b, c\}$ over time. The learning mechanism is based on recursive least squares, the principle of Kalman filtering. The mechanism is formalized

$$
\begin{aligned}
\xi_{t}^{i} & =\xi_{t-1}^{i}+\kappa_{t}^{i} R^{-1, i} X_{t}\left(Y_{t}-X_{t}^{\prime} \xi_{t-1}^{i}\right) . \\
R_{t}^{i} & =R_{t-1}^{i}+\kappa_{t}^{i}\left(X_{t} X_{t}^{\prime}-R_{t-1}^{i}\right) .
\end{aligned}
$$

where $i=\{P, C B\}, \xi_{t}^{i}=\left[\operatorname{vec}\left(\hat{a}^{i}\right)^{\prime} \operatorname{vec}\left(\hat{b}^{i}\right)^{\prime} \operatorname{vec}\left(\hat{c}^{i}\right)^{\prime}\right]^{\prime}$ the $(21 \mathrm{x} 1)$ vector of the perceivedlaw-of-motion parameters, $X_{t}$ is the $(21 \times 3)$ matrix of appropriately stacked exoge- 
nous shocks $s_{t}$ and $s_{t-1}, R_{t}^{i}$ is the variance-covariance matrix of the parameters, and $\kappa_{t}^{i}$ is the information gain.

Definition 1. Knowledge heterogeneity Agents in the model (6)-(8) differ in their knowledge of the structural parameters, and in the speed of updating their knowledge. The individual information sets are defined as

$$
\begin{gathered}
\Omega_{t}^{P}=\left\{\hat{a}_{t}^{P}, \hat{b}_{t}^{P}, \hat{b}_{t}^{P} \kappa_{t}^{P}, s_{t}, s_{t-1}\right\}, \\
\Omega_{t}^{C B}=\left\{\hat{a}_{t}^{C B}, \hat{b}_{t}^{C B}, \hat{b}_{t}^{C B} \kappa_{t}^{C B}, s_{t}, s_{t-1}\right\} .
\end{gathered}
$$

To analyze the conditions under which the imperfect knowledge model (6)(10) converges to the REE equilibrium, the methodology developed by Evans \& Honkapohja (2001) is employed. In principle the methodology consists of two parts. First, the rational expectation equilibrium of a given model is examined. We look for conditions under which the REE is determined. The REE equilibrium is called to be determined if it is found unique and stabile. The second part of the methodology is the check for the learnability of REE. The question is, if the economic agents have imperfect knowledge, can they learn, given a learning mechanism, the true RE dynamics? Throughout the paper the recursive, least-squares (econometric) learning mechanism (34)-(35) is considered. The conditions that guarantee the REE is attainable under the adaptive learning mechanism are called the E-stability conditions. For technical details on the methodology we refer to Evans \& Honkapohja (2001) and Evans \& Honkapohja (2003) where the adaptive learning in a homogenous environment is examined and to Honkapohja \& Mitra (2003) for the methodology on heterogenous learning. 


\subsection{REE Determinacy}

To examine the rational expectation equilibrium of the model (6)-(8) we begin with rewriting the model into a matrix structural form:

$$
Y_{t}=A_{0}+A_{1} \hat{E}_{t}^{P} Y_{t+1}+A_{2} \hat{E}_{t}^{C B} Y_{t+1}+A_{3} \hat{E}_{t-1}^{P} Y_{t}+A_{4} Y_{t}+s_{t}
$$

where $Y_{t}=\left(x_{t}, \pi_{t}, i^{C B}\right)^{\prime}, s_{t}=\left(v_{t}, u_{t}, 0\right)^{\prime}, A_{0}=\left[\begin{array}{lll}0 & 0 & -\theta_{1} \pi^{*}\end{array}\right]^{\prime}$,

$$
A_{1}=\left[\begin{array}{ccc}
1 & \sigma & 0 \\
0 & \beta & 0 \\
0 & 0 & 0
\end{array}\right], A_{2}=\left[\begin{array}{ccc}
0 & 0 & 0 \\
0 & 0 & 0 \\
\theta_{2} & \theta_{1} & 0
\end{array}\right], A_{3}=\left[\begin{array}{ccc}
0 & 0 & -\sigma \\
0 & 0 & 0 \\
0 & 0 & 0
\end{array}\right], A_{4}=\left[\begin{array}{ccc}
0 & 0 & 0 \\
\lambda & 0 & \gamma \\
0 & 0 & 0
\end{array}\right] .
$$

The properties of $u_{t}$ and $v_{t}$ determine $s_{t}$ so that it follows an $\mathrm{AR}(1)$ process $s_{t}=$ $F s_{t-1}+w_{t}$, where

$$
F=\left[\begin{array}{ccc}
\rho_{A} & 0 & 0 \\
0 & \rho_{c} & 0 \\
0 & 0 & 0
\end{array}\right] \quad w_{t}=\left[\begin{array}{c}
\nu_{t}^{v} \\
\nu_{t}^{c} \\
0
\end{array}\right]
$$

recalling that we assume $\rho_{A}=\rho_{c}=\rho$ and $\nu_{t}^{v}=\frac{\sigma(1+\phi)\left(1-\rho_{A}\right)}{1+\sigma \phi} \nu_{t}^{A}-\frac{\sigma\left(1+\rho_{c}-2 \sigma \phi\right)}{1+\sigma \phi} \nu_{t}^{c}$.

The reduced form to the structural model (36) is

$$
Y_{t}=M_{0}+M_{1} \hat{E}_{t}^{P} Y_{t+1}+M_{2} \hat{E}_{t}^{C B} Y_{t+1}+M_{3} \hat{E}_{t-1}^{P} Y_{t}+P s_{t}
$$

where $M_{0}=P M_{0}, M_{1}=P A_{1}, M_{2}=P A_{2}, M_{3}=P A_{3}$, and $P=\left(I-A_{4}\right)^{-1}$.

To analyze the REE determinacy, we will assume for now a perfect knowledge environment, $\hat{E}_{t}^{P}()=.\hat{E}_{t}^{C B}()=.E_{t}(.) . E_{t-1} Y_{t}$ can be rewritten as $Y_{t}=E_{t-1} Y_{t}+\eta_{t}$, where $\eta_{t}$ is the innovation term which under the REH follows a stationary process. 
Given that and rearranging the reduced form one obtains

$$
Y_{t}=C+M E_{t} Y_{t+1}+Q s_{t}+Q A_{3} \eta_{t}
$$

where $C=Q A_{0}, M=Q\left(A_{1}+A_{2}\right)$, and $Q=\left(I-A_{3}-A_{4}\right)^{-1}$.

Proposition 1. The model (6)-(8) has a unique and stabile rational expectations equilibrium if the modulus of the eigenvalues of matrix $M$ in (38) lies inside the unit circle.

Proof follows from the properties of the stable FODE system.

\subsection{E-Stability}

The second issue is to analyze the conditions under which the REE is learnable. We will follow the methodology by Evans \& Honkapohja (2003) for the heterogenous adaptive learning based on recursive least squares. If the REE is determined, the model has the minimum state variable (MSV) representation

$$
Y_{t}=a+b s_{t}+c s_{t-1}
$$

$a, b$, and $c$ are the $(3 \times 1)$ and $(3 \times 3)$ matrices of the model primitives. Their exact form is derived in Appendix B on page 38 .

Next suppose, the agents have the following perceived law of motion (PLM). The private agents' PLM is

$$
Y_{t}=\hat{a}_{t}^{P}+\hat{b}_{t}^{P} s_{t}+\hat{c}_{t}^{P} s_{t-1}
$$

and of the central bank's PLM

$$
Y_{t}=\hat{a}_{t}^{C B}+\hat{b}_{t}^{C B} s_{t}+\hat{c}_{t}^{C B} s_{t-1}
$$


The subscript $t$ at matrices indicates the time dependence of the matrices as the agents are learning using (9)-(10). The private agents and central bank use their PLMs to form expectations

$$
\begin{aligned}
\hat{E}_{t}^{P} Y_{t+1} & =\hat{a}_{t}^{P}+\left(\hat{b}_{t}^{P} F+\hat{c}_{t}^{P}\right) s_{t}, \\
\hat{E}_{t-1}^{P} Y_{t} & =\hat{a}_{t}^{P}+\left(\hat{b}_{t}^{P} F+\hat{c}_{t}^{P}\right) s_{t-1}, \\
\hat{E}_{t}^{C B} Y_{t+1} & =\hat{a}_{t}^{C B}+\left(\hat{b}_{t}^{C B} F+\hat{c}_{t}^{C B}\right) s_{t} .
\end{aligned}
$$

Substituting (17)-(19) back to the reduced form (12), one obtains the economy's actual law of motion

$$
\begin{aligned}
Y_{t}= & {\left[M_{0}+\left(M_{1}+M_{3}\right) \hat{a}_{t}^{P}+M_{2} \hat{a}_{t}^{C B}\right]+} \\
& +\left[P+M_{1}\left(\hat{b}_{t}^{P} F+\hat{c}_{t}^{P}\right)+M_{2}\left(\hat{b}_{t}^{C B} F+\hat{c}_{t}^{C B}\right)\right] s_{t}+M_{3}\left(\hat{b}_{t}^{P} F+\hat{c}_{t}^{P}\right) s_{t-1} .
\end{aligned}
$$

The mapping from PLM to ALM is formalized to

$$
\begin{aligned}
T[a, b, c]= & {\left[M_{0}+\left(M_{1}+M_{3}\right) \hat{a}_{t}^{P}+M_{2} \hat{a}_{t}^{C B},\right.} \\
& P+M_{1}\left(\hat{b}_{t}^{P} F+\hat{c}_{t}^{P}\right)+M_{2}\left(\hat{b}_{t}^{C B} F+\hat{c}_{t}^{C B}\right), \\
& \left.M_{3}\left(\hat{b}_{t}^{P}+\hat{c}_{t}^{P}\right)\right] .
\end{aligned}
$$

The E-stability is determined by the differential equation

$$
\frac{d}{d \tau}(a, b, c)=T[a, b, c]-(a, b, c)
$$

Evans \& Honkapohja (2001) prove the E-stability exists if (22) is locally stable. Honkapohja \& Mitra (2003) and Evans \& Honkapohja (2003) show the map (21) can be simplified. They show the E-stability conditions in the case of heterogenous 
expectations are equivalent (under least squares learning) to the homogenous expectations case. Thus (46), assuming $\hat{j}_{t}^{P}=\hat{j}_{t}^{C B}=\hat{j}_{t}$ for $j=\{a, b, c\}$, simplifies to

$$
T[a, b, c]=\left[M_{0}+\left(M_{1}+M_{2}+M_{3}\right) \hat{a}_{t}, P+\left(M_{1}+M_{2}\right)\left(\hat{b}_{t} F+\hat{c}_{t}\right), M_{3}\left(\hat{b}_{t} F+\hat{c}_{t}\right)\right] .
$$

Proposition 2. The REE of the model (6)-(10) is E-stable under heterogenous expectations if and only if the corresponding model with homogenous expectations is E-stable. Hence the modulus of eigenvalues of

$$
\begin{aligned}
D T_{a}(a) & =I \otimes\left(M_{1}+M_{2}+M_{3}\right) \\
D T_{b}(b) & =F^{\prime} \otimes\left(M_{1}+M_{2}\right) \\
D T_{c}(c) & =I \otimes M_{3}
\end{aligned}
$$

must lie inside the unit circle.

Proof see Evans \& Honkapohja (2003) for the proof of the first statement and Appendix $\mathrm{C}$ on page 40 for the derivation of $D T_{a}(a), D T_{b}(b)$, and $D T_{c}(c)$.

\subsection{Numerical Evaluation of the Conditions}

Since $M$ is a $(3 \times 3)$ matrix, it is easier to evaluate the REE determinacy and Estability conditions numerically. Ravenna \& Walsh (2003) estimate the model (6)-(8) on US data. Since their results are very close to Clarida, Gali \& Gertler (2000) we combine them to calibrate the model. We set $\beta=0.99, \lambda=0.075, \sigma=4$, $\theta=0.75$. The implied value of $\gamma=\frac{(1-\theta)(1-\theta \beta)}{\theta}$ is 0.08 .

The numerical evaluation of the determinacy and E-stability conditions for our workhorse model (6)-(10) are summarized in Figure 1. For comparison, we also report results on how the conditions change if the credit channel is closed $(\gamma=0)$, 
i.e., firms are not required to pay wages in advance. The results are summarized in Figure 2. We can see they are equivalent to the results obtained by Bullard \& Mitra (2002).

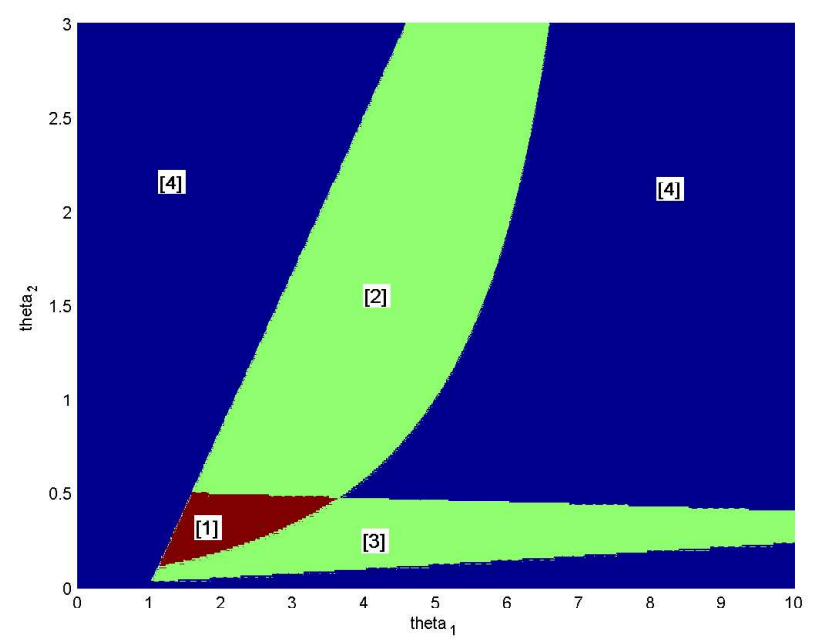

Figure 1: Numerical evaluation of the REE determinacy and E-stability conditions when $\gamma=0.08$. Legend: [1] determinate and E-stable, [2] indeterminate and Estable, [3] determinate and E-unstable, [4] indeterminate and E-unstable region.

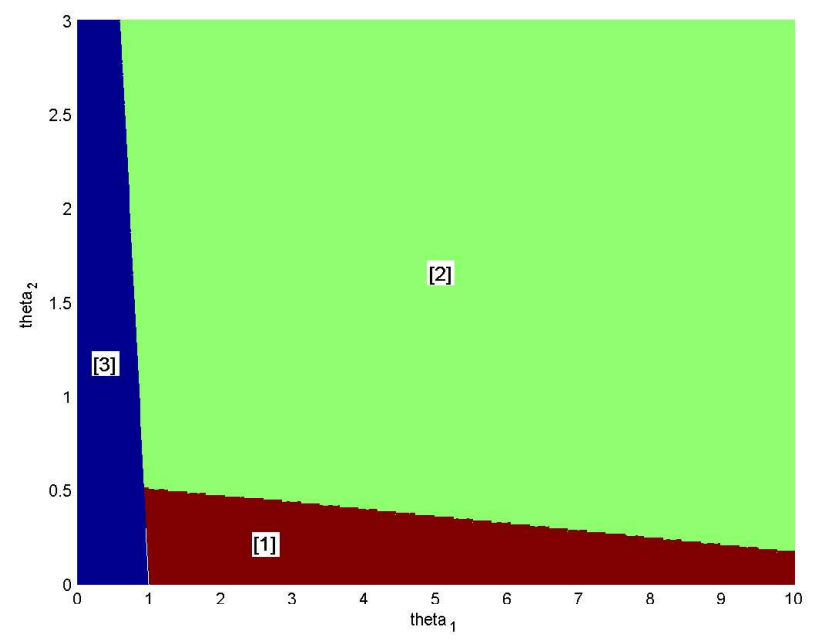

Figure 2: Numerical evaluation of the REE determinacy and E-stability conditions when the credit channel is closed $(\gamma=0)$. Legend: [1] determinate and E-stable, [2] indeterminate and E-stable, [3] indeterminate and E-unstable region. 
From the graphical evaluation of the conditions it follows, the central bank has a considerably limited manoeuvering space for setting its policy rule. The model without a banking sector implies the central bank has the option to set its $\theta_{\pi}$ and $\theta_{x}$ in the ranges of $(1,12)$ and $(0,0.5)$, respectively. ${ }^{1}$ In the model with the banking sector this is already considerably less. To impose determinacy and E-stability, $\theta_{\pi}$ and $\theta_{x}$ must be within $(1,3.5)$ and $\left.0.1,0.5\right)$, respectively. In this light the calibration of policy rule (8) where $\theta_{\pi}=1.5$ and $\theta_{x}=0.5$, often used in the literature, puts the model equilibrium on the edge of determinacy and E-stability. In simulations below we choose $\theta_{x}=0.4$ to be within the E-stability and determinacy region.

\section{Model simulation}

In this section, we focus on the two research questions asked in the introductory part, i.e., (i) does it help to decrease the economic variability if the central bank has better knowledge?, and (ii) should the central bank be more inflation or output-gap averse in order to lower the economic variability? In the fashion of Orphanides \& Williams (2003), the questions will be addressed using simulations based on constant-gain learning. The simulation results on economic variability implied by different model settings are summarized in Table 1 and 3. Appendix D on page 41 contains details on the simulation.

Given the amount of simulation results, we focus on summary statistics of economic variability. We call this variability as implied by the learning process. Even an economy without being subject to exogenous shocks can fluctuate. This is given by the knowledge heterogeneity and adaptive learning of agents. Any difference of expectations from the reality causes shock (surprise) and implies economic fluctuations (adjustments). The results below are obtained by assuming no exogenous shock to the economy, i.e., $\sigma_{u}^{2}=\sigma_{v}^{2}=0$. The implied economic system variability

\footnotetext{
${ }^{1}$ The upper limits obviously depend on the model numerical calibration.
} 
is the reaction on learning. Detailed results on parameters' estimates and their standard errors can be obtained, together with the codes generating those results, upon request from the author. 


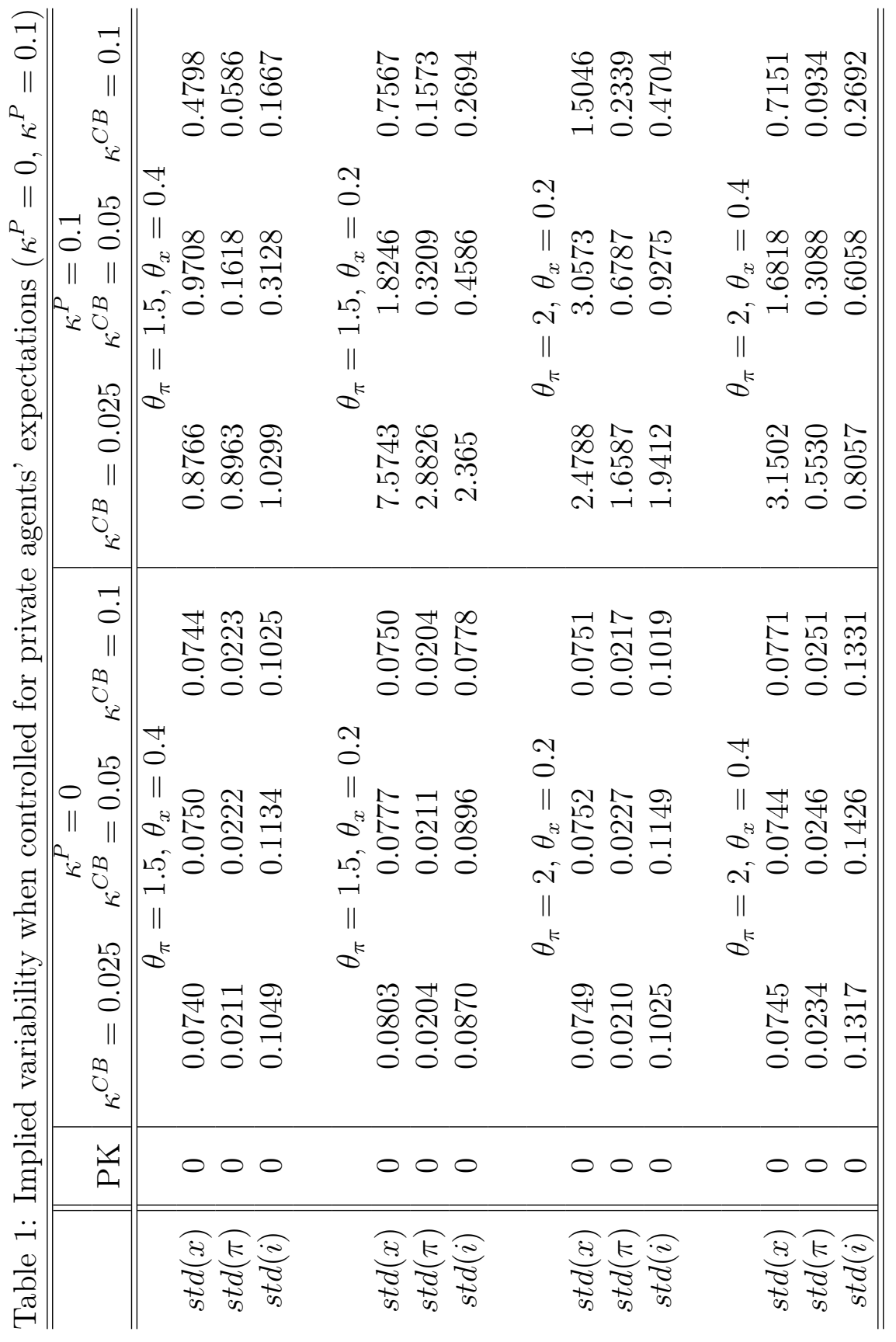




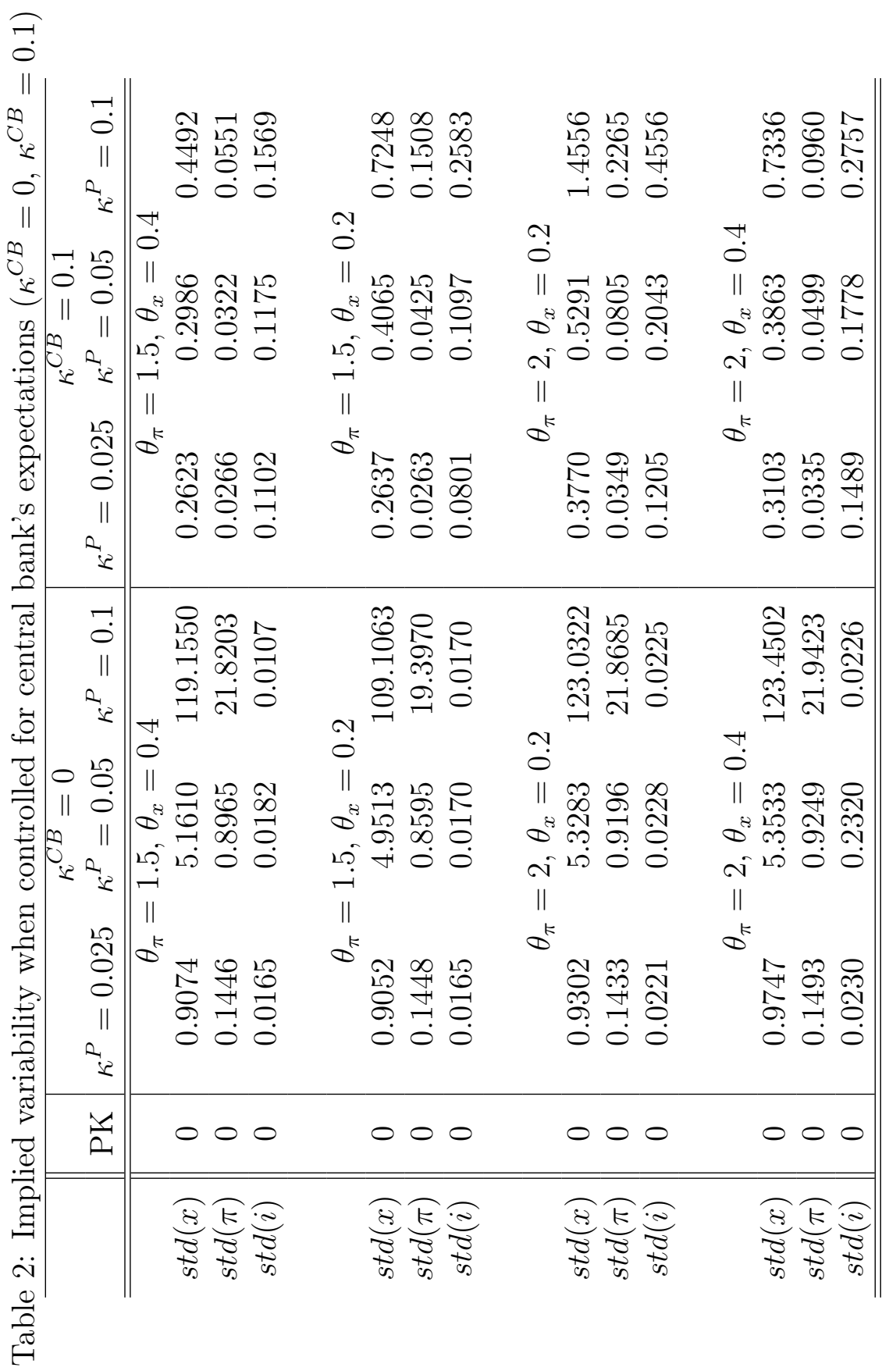




\subsection{Does better knowledge matter?}

This question is analytically examined in forthcoming Fukac (2005) where we look at the speed of convergence to the REE from the perspective of heterogenous knowledge, adaptive learning, and monetary policy set-up. In this section, we present numerical results which have motivated the closer analytical investigation on this problem.

The use of the term knowledge might seem to be misleading. In fact, what is called knowledge below can be also viewed as a willingness to learn. The higher the $\kappa$ 's value, the higher willingness to adjust a model. The employed terminology is motivated by the numerical experiment specification. The REE is considered as the initial economic state. Assigning different values to $\kappa_{i}$ causes a deviation from the REE. $\kappa_{i}$ being the Kalman gain, it reflects accumulated knowledge. The lower its value the more information is accumulated.

In Table 1 we can observe the following patterns. (i) If the private agents have better knowledge than the central bank, i.e., $\kappa^{P}<\kappa^{C B}$, the implied economic variability by the learning process is low. The variability is slightly increasing with the knowledge difference, however not in a significant way. This holds for all the settings of policy parameters considered. (ii) If the private agents have worse knowledge than the central bank, i.e., $\kappa^{P}>\kappa^{C B}$, the economic variability implied by the learning process itself is considerably higher than in the previous case. The variability is, however, decreasing with the lower knowledge difference. Again, as knowledge is becoming homogenous $\left(\kappa^{P}=\kappa^{C B}=0.1\right)$, the implied variability is the lowest.

Table 3 contains somewhat surprising results. (i) When the central bank has better knowledge than the private agents the variability is relatively high. It increases dramatically as the private agents' knowledge is worsening relatively to 
the central bank's knowledge. (ii) Remarkably, when the central bank has worse knowledge than the private agents $\left(\kappa^{P}<\kappa^{C B}=0.1\right)$, the implied variability is low (increasing as the knowledge is getting homogenous), which is exactly the opposite what is found for the central bank case in Table 1 . When the central bank has worse knowledge than the private sector, with the knowledge homogenization, the implied economic variability lowers. However, when the private agents have better knowledge, the knowledge homogenization is increasing the variability. The observations are robust to all policy settings considered.

The results favor the case of knowledge homogeneity. When the private agents and central bank share the same knowledge, the implied economic variability is low, even if the knowledge is not perfect, e.g., $\kappa=0.1$. On the other hand, knowledge heterogeneity may cause problems. Big differences in knowledge imply considerably high economic fluctuations, especially if the knowledge asymmetry favors the central bank. Interestingly, high economic volatility does not occur if the private agents exhibit better knowledge than the central bank.

\subsection{Inflation or output gap hawkiness?}

Now we evaluate the results in Table 1 and 3 from the perspective of monetary policy setting.

$\theta_{\pi}=1.5$ and $\theta_{x}=0.4$ is the policy configuration which delivers the lowest implied economic variability for all states of knowledge in the economy. This will be our benchmark. If the policy is tougher on inflation $\left(\theta_{\pi}=2\right.$ and $\left.\theta_{x}=0.4\right)$, the economic variability implied by learning increases. In the case where private agents have worse knowledge than the central bank (Table $1, \kappa^{P}=0.1$ ), the variability even doubles. In Table 3, the increase is not as significant.

When the policy is less focused on the output gap stabilization, i.e., $\theta_{\pi}=1.5$ and $\theta_{x}=0.2$, it yields considerably higher variability, with respect to the benchmark 
case, and the private agents having worse knowledge than the central bank (Table $1, \kappa^{P}=0.1$ ). The variability is about the same when the situation is reverse (Table $\left.3, \kappa^{C B}=0.1\right)$.

When the central bank prefers inflation stabilization over the output gap stabilization, i.e., $\theta_{\pi}=2$ and $\theta_{x}=0.2$, there are some gains and the variability lowers in comparison to the benchmark in Table 1. In Table 3, where the private agents have better knowledge than the central bank, the result is reverse, i.e., the variability increases with a tougher policy on inflation.

To sum up, the policy configuration $\theta_{\pi}=1.5$ and $\theta_{x}=0.4$ is robust and delivers the lowest economic variability implied by the learning process. A different policy setting does not seem to deliver better results. There is no evidence the central bank ought to prefer to be inflation hawk to the output gap hawk. It is common for both cases though, when $\theta_{\pi}=1.5$ or 2 , to be less output gap averse which increases the variability. 


\section{Summary and Conclusion}

In recent years, one can observe a rising interest of economists in the question of optimal monetary policy in an imperfect and heterogenous knowledge environment. The central question asked in this paper 'Should private expectations concern central bankers?' is common to most of the literature. Here, the question has been reviewed form a slightly different perspective.

Borrowing from the RBC literature, we have extended the standard New Keynesian for a financial intermediation sector which in reality plays an important role in policy transmission. In the theory, it is often omitted. Since, in the model, private banks have to form expectations about the future central bank's actions in order to price their products, misperceiving future policy actions may cause distortions in monetary policy actions, which would have consequences for the economic dynamics.

The workhorse model consists, in a standard way, of the IS curve which captures the output gap dynamics, the Phillips curve describing the inflation dynamics, and the policy rule. The model differs from the standard New Keynesian set-up in one important way. The interest rate does influence not only the output gap but it affects directly the inflation dynamics as well. Consequently, the monetary policy leading to the REE determinacy and E-stability is very restricted in this model. The central bank has only limited maneuvering space for the inflation and output gap stabilization, in comparison for instance to Bullard \& Mitra (2002).

The simulation results suggest 'the world is simpler if knowledge and beliefs are homogenous'. The functioning of homogenous-knowledge models is well understood. For instance, the recommendation of being inflation and output gap hawk can be applied. If the knowledge is homogenous, it helps to speed up the learning of the REE dynamics. ${ }^{2}$ If knowledge and beliefs are heterogenous, the

\footnotetext{
${ }^{2}$ Ferrero (2003) provides an excellent analysis in this respect.
} 
results suggest the policy ought not to be hawkish neither towards inflation nor the output gap. Since it leads to a higher implied economic variability, it prolongs the learning process of REE and potentially may lead to an instability (depending on the knowledge heterogenity magnitude). For the central bank to play its role effectively in the heterogenous information world and help the economy converge to the first best equilibrium, it ought to be conservative in its actions and focus its policy on the information and knowledge homogenization in the economy.

In principle, there are two possibilities to do this. First, the central bank can adopt, in its policy function, expectations of the private sector. This is the simplest way. This, however, brings the requirement the central bank is able to observe (measure) the true market expectations. Certainly, this may not be as simple as it seems. Expectations census may raise unreliable data. The second possible solution to the homogenous expectations problem is that the private sector adopts in its decision rules the central bank's expectations. The central bank forms its own forecasts which disseminates across the economy, and the private agents accept them as their own. This confirms good communication with the private sector, and policy credibility is the key issue for policy effectiveness and optimality.

To go one way or another, private agents' expectations ought to concern central bankers. To know their exact form improves the policy quality. If central banks base their policy on their own beliefs without appropriately revealing them, it may cause excess economic variability. 


\section{References}

Bullard, J. \& K. Mitra (2002), 'Learning about monetary policy rules', Journal of Monetary Economics 49, 1105-1129.

Christiano, L. J. \& M. Eichenbaum (1992), 'Liquidity effects and the monetary transmission mechanism', American Economic Review 82(3), 346-353.

Clarida, R., J. Gali \& M. Gertler (2000), 'Monetary policy rules and macroeconomic stability: Evidence and some theory', Quarterly Journal of Economics 115, 147-180.

Evans, G.W. (2003), 'Comment on 'imperfect knowledge, inflation expectations, and monetary policy' by a. orphanides and j. c. williams', mimeo (Available at http://www.uoregon.edu/gevans/OrphWillComNBER.pdf).

Evans, G.W. \& S. Honkapohja (2001), Learning and Expectations in Macroeconomics, 2 edn, Princeton University Press, New Jersey.

Evans, G.W. \& S. Honkapohja (2003), 'Adaptive learning and monetary policy design', Journal of Money, Credit and Banking 35, 1045-1072.

Ferrero, G. (2003), Monetary policy and the transition to rational expectations, Dissertation thesis, Universitat Pompeu Fabra.

Fuerst, T. (1992), 'Liquidity, loanable funds, and real activity', Journal of Monetary Economics 29, 3-24.

Fukac, M. (2005), 'Imperfect, heterogenous knowledge and monetary policy', mimeo (Available at http://home.cerge-ei.cz/fukac/papers).

Gali, J. \& M. Gertler (1999), 'Inflation dynamics: A structural econometrics analysis', Journal of Economics Analysis 44(2), 195-222.

Gust, Ch. J. \& L.J. Christiano (1999), 'Taylor rules in a limited participation model', De Economist 147, 437-60.

Honkapohja, S. \& K. Mitra (2003), 'Performance of monetary policy with internal central bank forecasting', Journal of Economic Dynamics and Control (forthcoming).

Honkapohja, S., K. Mitra \& G.W. Evans (2003), 'Notes on agents' behavioral rules under adaptive learning and receant studies of monetary policy', mimeo (Available at http://www.uoregon.edu/gevans/).

Malik, H.A. (2004), 'The cost channel in the new keynesian model: Comparing inflation targeting and price level targeting', mimeo .

Orphanides, A. \& J.C. Williams (2003), 'Imperfect knowledge, inflation expectations, and monetary policy', NBER Working Paper (9884). 
Preston, B. (2004), 'Adaptive learning, forecast-based instrument rules and monetary policy', Journal of Monetary Economics (forthcoming).

Ravenna, F. \& C. E. Walsh (2003), 'The cost chanel in a new keynesian model: Evidence and implications', mimeo (Available at http://ic.ucsc.edu/ fravenna/home/). 


\section{Appendix A}

In this appendix we derive the model (1)-(5) from first principles.

\section{Agents}

Households The households' objective is to maximize lifetime utility. The consumption bundle, $c_{t}$, and leisure, $\left(1-N_{t}\right)$, deliver the utility. To meet the objective, a household does not only decide about how much to consume and how much to work, but it also decides about how much money to hold, since money is the means of transaction in this economy and serves the consumption-smoothing purposes. Households face two constraints in their decisions. First, following Fuerst (1992), they need to hold cash in advance in order to purchase consumption goods. The decision about $M_{t}^{c}$ is made at the end of the period $t-1$. Disposable income in period $t$ is $W_{t} N_{t}$, where $W_{t}$ is the nominal wage and $N_{t}$ is the hours worked. A budget constraint is second constraint the households face. It equates the current period income from labour $\left(W_{t} N_{t}\right)$, financial assets $\left(M_{t}^{c}+\left(1+i_{t}^{d}\right) M_{t}^{d}\right)$ and the ownership of firms $\left(\Pi_{t}^{f}\right)$ and banks $\left(\Pi_{t}^{b}\right)$, to the value of current period consumption $\left(P_{t} c_{t}\right)$ and financial portfolio carried to the next period $\left(M_{t+1}\right)$. The representative household's problem can be formally written as

$$
\max _{\left\{c_{t}, N_{t}, M_{t+1}^{c}, M_{t+1}^{d}\right\}_{t=0}^{\infty}} \sum_{t=0}^{\infty} \beta^{t} E_{0}\left(\frac{c_{t}^{1-\frac{1}{\sigma}}}{1-\frac{1}{\sigma}} \exp \left(\varepsilon_{t}^{c}\right)-\psi \frac{N_{t}^{1+\phi}}{1+\phi}\right)
$$

subject to

$$
\begin{aligned}
M_{t}^{c}+W_{t} N_{t} & \geq P_{t} c_{t}, \\
M_{t+1}+P_{t} c_{t} & =M_{t}^{c}+\left(1+i_{t}^{d}\right) M_{t}^{d}+W_{t} N_{t}+\Pi_{t}^{f}+\Pi_{t}^{b}, \\
M_{t} & =M_{t}^{c}+M_{t}^{d} .
\end{aligned}
$$


Here $c_{t}$ represents the CES composite index (Dixit-Stiglitz aggregator) of real consumption, $c_{t}=\left(\int_{0}^{1} c_{t}(i)^{\frac{\epsilon-1}{\epsilon}} d i\right)^{\frac{\epsilon}{\epsilon-1}}$ with $c_{t}(i)$ being the consumption of differentiated good $i$ and $\epsilon>1 ; P_{t}=\left(\int_{0}^{1} P_{t}(i)^{1-\epsilon} d i\right)^{\frac{1}{1-\epsilon}}$ is the corresponding nominal price index, with $P_{t}(i)$ being the price of the differentiated good $i . N_{t}$ is the hours worked, $M_{t}^{c}$ is cash money, $M_{t}^{d}$ is deposit money, $\Pi_{t}^{f}$ is the profit coming from the firm ownership, $\Pi_{t}^{b}$ is the profit from the bank ownership, $W_{t}$ is the nominal wage, and $i_{t}^{d}$ is the nominal return on the deposit money. $\varepsilon_{t}^{c}$ is the preference shock which is assumed to follow an $\operatorname{AR}(1)$ process $\varepsilon_{t}^{c}=\rho_{c} \varepsilon_{t-1}^{c}+\nu_{t}^{c}$, with $\nu_{t}^{c}$ being iid with zero mean and finite variance, and $0<\rho_{c}<1 . \beta, \phi$ and $\psi$ are scalars between 0 and 1 , and $\sigma>1$.

Setting up the Lagrangian function

$$
\begin{aligned}
L\left(c_{t}, N_{t}, M_{t+1}^{c}, M_{t+1}^{d}\right)= & \sum_{t=0}^{\infty} \beta^{t} E_{t}\left(\frac{c_{t}^{1-\frac{1}{\sigma}}}{1-\frac{1}{\sigma}} \exp \left(\varepsilon_{t}^{c}\right)-\psi \frac{N_{t}^{1+\phi}}{1+\phi}\right)+ \\
& +\lambda_{1, t}\left(M_{t}^{c}+W_{t} N_{t}-P_{t} c_{t}\right) \\
& +\lambda_{2, t}\left[M_{t}^{c}+\left(1+i_{t}^{d}\right) M_{t}^{d}+W_{t} N_{t}+\Pi_{t}^{f}+\Pi_{t}^{b}-P_{t} c_{t}-M_{t+1}^{c}-M_{t+1}^{d}\right] .
\end{aligned}
$$

and maximizing it gives a set of first order conditions

$$
\begin{aligned}
\frac{\partial L(.)}{\partial c_{t}} & =\beta^{t} c_{t}^{-1 / \sigma} \exp \left(\varepsilon_{t}^{c}\right)-\lambda_{1, t} P_{t}-\lambda_{2, t} P_{t}=0 \\
\frac{\partial L(.)}{\partial N_{t}} & =-\beta^{t} \psi N_{t}^{\phi}+\lambda_{1, t} W_{t}+\lambda_{2, t} W_{t}=0 \\
\frac{\partial L(.)}{\partial M_{t+1}^{d}} & =-\lambda_{2, t}+\left(1+i_{t+1}^{d}\right) \lambda_{2, t+1}=0 \\
\frac{\partial L(.)}{\partial M_{t+1}^{c}} & =-\lambda_{2, t}+\lambda_{1, t+1}+\lambda_{2, t+1}=0
\end{aligned}
$$

Combining (28), and (29) gives the Euler equation for the household's labour supply

$$
\frac{c_{t}^{-1 / \sigma}}{\psi N_{t}^{\phi}} \exp \left(\varepsilon_{t}^{c}\right)=\frac{P_{t}}{W_{t}} .
$$


Combining (28),(30) and (31) gives the Euler equation for consumption

$$
\frac{c_{t}^{-1 / \sigma}}{P_{t}} \exp \left(\varepsilon_{t}^{c}\right)=\beta\left(1+i_{t}^{d}\right) E_{t}\left(\frac{c_{t+1}^{-1 / \sigma}}{P_{t+1}} \exp \left(\varepsilon_{t+1}^{c}\right)\right)
$$

Having the relation for the aggregate consumption, we also have to solve for the individual demand for differentiated goods $c_{t}(i)$. Here the household solves

$$
\max _{c_{t}(i)} \quad c_{t}=\left(\int_{0}^{1} c_{t}(i)^{\frac{\epsilon-1}{\epsilon}} d i\right)^{\frac{\epsilon}{\epsilon-1}}
$$

subject to the budget constraint

$$
P_{t} c_{t}=\int_{0}^{1} c_{t}(i) P_{t}(i) d i
$$

where $P_{t} c_{t}$ are the expenditures on the consumption bundle $c_{t}$, and $P_{t}(i)$ is the price of an individual good. Solution to this problem is the individual good demand

$$
c_{t}(i)=\left(\frac{P_{t}(i)}{P_{t}}\right)^{-\epsilon} c_{t}
$$

In summary, constraints (25)-(27) and equations (32),(33), and (36) describe the household's optimal decisions.

Firms Firms operate in a monopolistically competitive environment. As such, to maximize their profits, they choose how much to produce, what price to charge, and how much labour to demand. Following the timing in Fuerst (1992), management's decisions are taken after the shocks to the economy are realized. We assume labour is the only production factor. To start production, a firm goes to the labour market to hire workers. Once the output is produced, the labour is paid out. The firm goes to a bank and applies for a credit to cover the wage bill. When the revenues from selling the output are collected, the firm re-pays the credit and 
transfers its net financial position to households.

Each firm, distinguished as an $i$ firm, produces one type of good and solves the following problem

$$
\max _{\left\{N_{t}(i), P_{t}(i), B_{t}(i)\right\}} E_{0} \sum_{t=0}^{\infty} \Phi_{t+1} \Pi_{t}^{f}(i)
$$

where $\Pi_{t}^{f}(i)=P_{t}(i) y_{t}(i)-W_{t} N_{t}(i)-i_{t}^{b} B_{t}$ is the firm's $i$ nominal profit and $\Phi_{t+1}$ is the stochastic discount factor defined as $\beta^{t+1} /\left(c_{t+1} P_{t+1}\right){ }^{3} N_{t}(i)$ is the labour demanded by the firm $i, P_{t}(i)$ is the firm-specific price charged on the output $y_{t}(i)$, $B_{t}(i)$ is the demand for credit, and $i_{t}^{b}$ is the interest rate paid for the credit. Note that the firm's problem is in fact static and thus the firm maximizes only $\Pi_{t}^{f}(i)$ subject to

$$
\begin{aligned}
y_{t}(i) & =A_{t} N_{t}(i), \\
y_{t}(i) & =\left(\frac{P_{t}(i)}{P_{t}}\right)^{-\epsilon} c_{t}, \\
W_{t} N_{t}(i) & \leq B_{t}(i) .
\end{aligned}
$$

(38) is the firm's production function where labour is the only production factor. The technology associated to the labour is captured by $A_{t}=\exp \left(\varepsilon_{t}^{A}\right)$, where $\varepsilon_{t}^{A}=$ $\rho_{A} \varepsilon_{t-1}^{A}+\nu_{t}^{A}$ is the aggregate technology shock, $\nu_{t}^{A}$ is iid, zero mean and finite variance disturbance, $0<\rho_{A}<1$. (39) is the demand function for the consumption good $c_{t}(i)$ the firm produces. The firm also faces a cash-in-advance constraint (40) which requires to pay wages in advance, i.e., after the output was produced but before it is sold.

Since in equilibrium (40) holds with equality, we substitute all the constraints

\footnotetext{
${ }^{3}$ It follows that if the firm acts in the best interest of the shareholder, the discount factor corresponds to the representative household's relative valuation of consumption across time.
} 
into the profit function and suitably rearrange to obtain

$$
\max _{P_{t}(i)} \quad \Pi_{t}^{f}=P_{t}(i)\left(\frac{P_{t}(i)}{P_{t}}\right)^{-\epsilon} c_{t}-\left(1+i_{t}^{b}\right) \frac{W_{t}}{A_{t}}\left(\frac{P_{t}(i)}{P_{t}}\right)^{-\epsilon} c_{t}
$$

The first order condition follows

$$
\frac{d \Pi_{t}^{f}}{d P_{t}(i)}=(1-\epsilon)\left(\frac{P_{t}(i)}{P_{t}}\right)^{-\epsilon} c_{t}+\epsilon\left(1+i_{t}^{b}\right) \frac{W_{t}}{A_{t}} P_{t}(i)^{-1}\left(\frac{P_{t}(i)}{P_{t}}\right)^{-\epsilon} c_{t}=0
$$

Rearranging it and using constraints (38)-(40) gives a set of conditions characterizing the optimal behavior of the $i$ 'th firm:

$$
\begin{aligned}
P_{t}(i) & =\frac{\epsilon}{\epsilon-1} M C_{t} \\
\frac{W_{t}}{P_{t}(i)} & =\frac{\epsilon-1}{\epsilon} \frac{1}{1+i_{t}^{b}} A_{t} \\
B_{t}(i) & =W_{t} N_{t}(i) .
\end{aligned}
$$

$M C_{t}$ are the firm's nominal marginal costs, $M C_{t}=\frac{\left(1+i_{t}^{b}\right) W_{t} N_{t}(i)}{y_{t}(i)}$. (41) is the standard pricing rule in the monopolistic competition. The price is a fixed markup over marginal costs, (42) is the labour demand, and (43) constitutes the credit demand function. Note that these conditions characterize the firm's optimal behavior in a frictionless environment.

To introduce a persistence into the prices in the model, Calvo's pricing scheme is assumed. The production sector is monopolistically competitive and as such has control over prices. Calvo's pricing mechanism assumes that in every period only a fraction of firms, $\theta \in(0,1)$, can adjust its price. The rest of the firms, $(1-\theta)$, charge the same price as in the previous period. $\theta$ is often viewed as a pricestickiness measure. The higher its value, the higher the degree of price persistence. Since the pricing mechanism is well known and described in the literature, we will limit ourselves to its optimal solution. 
Introducing Calvo's pricing mechanism, the firm's problem is no longer a static one. If a firm $i$ is allowed to change price in period $t$, it chooses to charge the optimal price

$$
P_{t}^{*}(i)=(1-\beta \theta) \sum_{k=0}^{\infty}(\beta \theta)^{k} E_{t}\left(M C_{t+k}\right),
$$

which is the discounted sum of the future expected marginal cost. Since we are in a monopolistically competitive environment, note that the marginal cost here meets the first order condition (41). This specification fully corresponds to the one employed in Gali \& Gertler (1999). $\beta$ is the subjective discount factor from the households problem. In this specification, the firm takes into account the possibility it might not be allowed to change the price for some time from now on.

Introducing the price persistence in the economy, the set of conditions (41)(43) characterizing the firm's optimal behavior in a monopolistically competitive environment is extended by the time dependent Calvo pricing rule (44). The firm applies it only if it wins the lottery and is allowed to change the price. Otherwise the firm charges the same price as in the previous period.

At this point, it is useful to determine the aggregate price level since later we will be particularly interested in the aggregate dynamics. As stated above, the aggregate price level is computed as

$$
P_{t}=\left(\int_{0}^{1} P_{t}(i)^{1-\epsilon} d i\right)^{\frac{1}{1-\epsilon}}
$$

The aggregate level in the sticky-price environment is a weighted average of past prices and new prices. The weights are given by the portion of firms allowed to change the prices. The aggregate price level becomes

$$
P_{t}=\left[(1-\theta) P_{t}^{*(1-\epsilon)}+\theta P_{t-1}^{1-\epsilon}\right]^{\frac{1}{1-\epsilon}}
$$

In summary, in the frictionless environment, the optimal behavior of firm is 
given by equations (41)-(43). If the Calvo pricing rule is introduced, (44) also applies. It is employed if the firm is allowed to change its price. Otherwise, it charges the price from the last period.

Banking Sector The role of the competitive banking sector is two-fold. First, to collect deposits from households and, second, to provide credit to firms. The operation schedule of the private bank is as follows. The bank enters the period $t$ with the deposit money from the households. The only money source in the economy is the central bank. Once the shocks to the economy are realized, and the central bank makes its decision about the policy rate, and firms decide on their production and credit demand, the private bank goes to the central bank and (i) puts the collected deposit money into its accounts and (ii) asks for a credit to cover the firms' demand. The central bank charges the same interest rate on both the deposit money and credit.

Households visit a bank before exogenous shocks are realized, i.e., at the end of period $t-1$. A private bank collects deposits and puts them on interest-bearing accounts at the central bank. As the central bank sets its rates after shocks are realized and the private bank has to sign contracts before that, the private bank has to form expectations about the central bank's future rate. From the perfect competition and zero profit condition it follows that the private bank sets its price as

$$
\begin{aligned}
i_{t}^{b} & =i_{t}^{C B}, \\
i_{t}^{d} & =E_{t-1} i_{t}^{C B},
\end{aligned}
$$

where $i_{t}^{b}$ is the interest rate charged on the credit provided to the firms, and $i_{t}^{d}$ is the interest rate offered on deposits. 
Monetary Authority The monetary policy, in order to anchor the nominal side of the economy, is assumed to follow the targeting rule

$$
i_{t}^{C B}=\theta_{\pi}\left(E_{t} \pi_{t+1}-\pi^{*}\right)+\theta_{x} E_{t} x_{t+1}
$$

where $i_{t}^{C B}$ is the policy instrument, $\pi_{t+1}$ is the inflation rate between periods $t$ and $t+1, x_{t+1}$ is the output gap in the $t+1$ period (see the definition below), $\pi^{*}$ is the inflation target. The target is set exogenously by the central bank and constitutes a nominal anchor to the economy. According to the rule, the central bank sets its policy instrument $i_{t}^{C B}$ on the basis of expected deviation of inflation from the target in the next period, and the expected output gap. $\theta_{\pi}$ and $\theta_{x}$ characterize the bank's preferences with respect to inflation stabilization and/or to the output gap stabilization. The higher value of $\theta$ 's, the more vigilant the bank is. The reason for the choice of policy rule (48) is twofold. First, the choice is motivated by the empirical evidence by Clarida et al. (2000) who argue for this type of rule. Second, Bullard \& Mitra (2002) find that this type of rule is robust to deliver the rational expectations equilibrium determinacy and E-stability, which is required for the analysis below.

\section{Model Equilibrium}

Definition 2. The flexible-price equilibrium is given by an allocation $\left\{c_{t}, N_{t}, M_{t+1}^{d}, M_{t+1}^{c}, B_{t}\right\}_{t=0}^{\infty}$ and set of $\left\{P_{t}, P_{t}(i), i_{t}^{b}, i_{t}^{d}, i_{t}^{C B}\right\}_{t=0}^{\infty}$ such that

1. households maximize their lifetime welfare (24) subject to constraints (25)$(26)$;

2. monopolistically competitive firms maximize their present-value profit (37) constrained by (38)-(40);

3. perfect competitive private banks maximize their profit; 
4. central bank meets its inflation target and zero-output-gap objectives; and

5. labour market, money market, and goods market clear.

Definition 3. The sticky-price equilibrium is given by an allocation $\left\{c_{t}, N_{t}, M_{t+1}^{d}, M_{t+1}^{c}, B_{t}\right\}_{t=0}^{\infty}$ and set of $\left\{P_{t}, P_{t}(i), i_{t}^{b}, i_{t}^{d}, i_{t}^{C B}\right\}_{t=0}^{\infty}$ such that

1. households maximize their lifetime welfare (24) subject to constraints (25)$(26)$;

2. monopolistically competitive firms maximize their present-value profit (37) constrained by (39)-(40), and Calvo's pricing principle allows the firm to set an optimal price according to (44) if it is allowed to change its price, otherwise $P_{t}(i)=P_{t-1}(i)$

3. perfect competitive private banks maximize their profit;

4. central bank meets its inflation target and zero-output-gap objectives; and

5. labour market, money market, and goods market clear.

\section{Log-Linearized Model and Aggregate Equilibrium}

From now on we focus our attention particularly on the aggregate dynamics. We log-linearize the sticky-price model and describe its aggregate-level dynamics. Because we concentrate specifically on the dynamics of output and inflation, we concentrate on the IS and Phillips curves.

First we derive the IS curve which characterizes the dynamics of output around its steady state. The derivation is straightforward and follows the same strategy as Ravenna \& Walsh (2003) and Malik (2004). We log-linearize the Euler equation from the household's problem (33) to get

$$
c_{t}=E_{t} c_{t+1}-\sigma\left(i_{t}^{d}-E_{t} \pi_{t+1}\right)+\sigma \varepsilon_{t}^{c} .
$$


From the market clearing condition it follows that $c_{t}=y_{t}$. If we define the output gap as $x_{t}=y_{t}-y_{t}^{f}$, then (49) becomes

$$
x_{t}=E_{t} x_{t+1}-\sigma\left(i_{t}^{d}-E_{t} \pi_{t+1}-r_{t}^{f}\right)+\sigma \varepsilon_{t}^{c},
$$

where $r_{t}^{f}$ is the real interest rate that arises in the frictionless equilibrium and $y_{t}^{f}$ is the output in the frictionless equilibrium. Both are defined as

$$
\begin{aligned}
r_{t}^{f} & =\left(\frac{1}{\sigma}\right) E_{t}\left(y_{t+1}^{f}-y_{t}^{f}\right)+\varepsilon_{t}^{c}, \\
y_{t}^{f} & =\frac{\sigma}{1+\sigma \phi}\left[\ln \left(\frac{\epsilon-1}{\epsilon}\right)-\ln \psi+(1+\phi) \varepsilon_{t}^{A}+\varepsilon_{t}^{c}-i_{t}^{d, f}\right],
\end{aligned}
$$

where $i_{t}^{d, f}$ is the nominal interest rate in the frictionless equilibrium. For computational convenience and without loss of generality, we will assume that this rate is equal to zero.

Eliminating $r_{t}^{f}$ from the above equation for the output gap we get

$$
x_{t}=E_{t} x_{t+1}-\sigma\left(i_{t}^{d}-E_{t} \pi_{t+1}\right)+v_{t},
$$

where $v_{t}=\frac{\sigma(1+\phi)\left(1-\rho_{A}\right)}{1+\sigma \phi} \varepsilon_{t}^{A}-\frac{\sigma\left(1+\rho_{c}-2 \sigma \phi\right)}{1+\sigma \phi} \varepsilon_{t}^{c}$. Recalling the properties of $\varepsilon_{t}^{A}$ and $\varepsilon_{t}^{c}$ and further assuming $\rho_{A}=\rho_{c}=\rho, v_{t}$ follows an $\mathrm{AR}(1)$ process $^{4}$. Equation (50) constitutes the IS curve as a function of expected future output gap and the ex ante real interest rate.

Second, we derive for the New Keynesian Phillips curve. Log-linearizing and combining (44) and (45) we obtain

$$
\pi_{t}=\beta E_{t} \pi_{t+1}+\frac{(1-\theta)(1-\theta \beta)}{\rho} m c_{t},
$$

\footnotetext{
${ }^{4}$ The process is $v_{t}=\rho v_{t-1}+\nu_{t}^{v}$, where $\nu_{t}^{v}=\frac{\sigma(1+\phi)\left(1-\rho_{A}\right)}{1+\sigma \phi} \nu_{t}^{A}-\frac{\sigma\left(1+\rho_{c}-2 \sigma \phi\right)}{1+\sigma \phi} \nu_{t}^{c}$.
} 
where $m c_{t}$ is the log of real marginal costs. To eliminate the marginal costs, we plug in (41) to (42) and divide both sides by $P_{t}$; we obtain the real marginal costs. Log-linearizing that under the perfect knowledge assumption gives

$$
m c_{t}=w_{t}-p_{t}+i_{t}^{b}-\varepsilon_{t}^{A}
$$

Substituting in (52) for the log-linearized labor supply function (32), gives

$$
m c_{t}=\frac{1+\sigma \phi}{\sigma} y_{t}-(1+\phi) \varepsilon_{t}^{A}+i_{t}^{b}
$$

We deduct $y_{t}^{f}$ from $m c_{t}$ to obtain $m c_{t}$ in terms of the output gap

$$
m c_{t}=\frac{1+\sigma \phi}{\sigma} x_{t}+i_{t}^{b}+\ln \left(\frac{\epsilon-1}{\epsilon}\right)-\ln \psi+\varepsilon_{t}^{c}
$$

Substituting this expression back to (51) gives the New Keynesian Phillips curve

$$
\pi_{t}=\beta E_{t} \pi_{t+1}+\lambda x_{t}+\gamma i_{t}^{b}+u_{t}
$$

where $\gamma=\frac{(1-\theta)(1-\theta \beta)}{\theta}, \lambda=\gamma \frac{1+\sigma \phi}{\sigma}$, and $u_{t}=\varepsilon_{t}^{c}$, assuming $\epsilon=\frac{1}{1-\psi}$. 


\section{Appendix B}

\section{MSV representation}

Using the method of undetermined coefficients, we derive the exact form of the minimum state variable (MSV) representation for the model considered in the text. Starting with the reduced form (12) and assuming rational expectations, i.e., $\hat{E}_{t}^{P}()=.\hat{E}_{t}^{C B}()=.E_{t}($.$) , we get$

$$
y_{t}=M_{0}+\left(M_{1}+M_{2}\right) E_{t} y_{t+1}+M_{3} E_{t-1} y_{t}+P \epsilon_{t}
$$

where

$$
\epsilon_{t}=F \epsilon_{t-1}+\varepsilon_{t}
$$

Now assume the MSV form takes the form

$$
y_{t}=a+b \epsilon_{t}+c \epsilon_{t-1}
$$

Taking the appropriate expectations needed in (54) one obtains

$$
\begin{aligned}
& E_{t} y_{t+1}=a+(b F+c) \epsilon_{t}, \\
& E_{t-1} y_{t}=a+(b F+c) \epsilon_{t-1} .
\end{aligned}
$$

Plugging these expectations back into (54) yields

$$
y_{t}=M_{0}+\left(M_{1}+M_{2}+M_{3}\right) a+\left[\left(M_{1}+M_{2}\right)(b F+c)+P\right] \epsilon_{t}+M_{3}(b F+c) \epsilon_{t-1} .
$$


Using the method of undetermined coefficients, it follows that the MSV solution must satisfy

$$
\begin{aligned}
M_{0}+\left(M_{1}+M_{2}+M_{3}\right) a & =a, \\
\left(M_{1}+M_{2}\right)(b F+c)+P & =b, \\
M_{3}(b F+c) & =c .
\end{aligned}
$$

Solving for the matrices $a, b$, and $c$ we get

$$
\begin{aligned}
a & =\left(I-M_{1}-M_{2}-M_{3}\right)^{-1} M_{0}, \\
\operatorname{vec}(b) & =\left[\mathbf{I}-F^{\prime} \otimes\left(M_{1}+M_{2}\right)-F^{\prime} \otimes\left(M_{1}+M_{2}\right)\left(I-M_{3}\right)^{-1} M_{3}\right]^{-1} \operatorname{vec}(P), \\
c & =\left(I-M_{3}\right)^{-1} M_{3} b F .
\end{aligned}
$$




\section{Appendix C}

Here we derive the matrices used in Proposition 2 on page 14 .

Having the map from the PLMs to ALM

$$
T[a, b, c]=\left[M_{0}+\left(M_{1}+M_{2}+M_{3}\right) \hat{a}_{t}, P+\left(M_{1}+M_{2}\right)\left(\hat{b}_{t} F+\hat{c}_{t}\right), M_{3}\left(\hat{b}_{t} F+\hat{c}_{t}\right)\right] .
$$

we take derivatives with respect to $\hat{a}_{t}, \hat{b}_{t}$, and $\hat{c}_{t}$. Using the rules for the derivatives of matrices we get

$$
\begin{aligned}
D T_{a}(a) & =\frac{d}{d \hat{a}_{t}}\left[M_{0}+\left(M_{1}+M_{2}+M_{3}\right) \hat{a}_{t}\right]=I \otimes\left(M_{1}+M_{2}+M_{3}\right), \\
D T_{b}(b) & =\frac{d}{d \hat{b}_{t}}\left[P+\left(M_{1}+M_{2}\right)\left(\hat{b}_{t}+\hat{c}_{t}\right)\right]=F^{\prime} \otimes\left(M_{1}+M_{2}\right), \\
D T_{c}(c) & =\frac{d}{d \hat{b}_{t}}\left[M_{3}\left(\hat{b}_{t} F+\hat{c}_{t}\right)\right]=I \otimes M_{3} .
\end{aligned}
$$




\section{Appendix D}

Here the details on simulation results are provided. The results presented below are obtained for the following numerical calibration: $\beta=0.99, \lambda=0.075, \sigma=4$, $\gamma=0.1, \theta_{\pi}=1.5, \theta_{x}=0.4, \pi^{*}=0, \rho=0.8, \sigma_{\nu}^{v}=0.1, \sigma_{\nu}^{c}=0.2$.

\section{The REE Model Dynamics}

Given the numerical calibration, we simulate the impulse response function for the standard New Keynesian model and for the credit channel extension. The impulse responses to the productivity and demand shocks are summarized in Figure 3. In Table ,3 we report on the moments, correlation and autocorrelation of the simulated variables. The numbers are obtained for 5,000 replications.
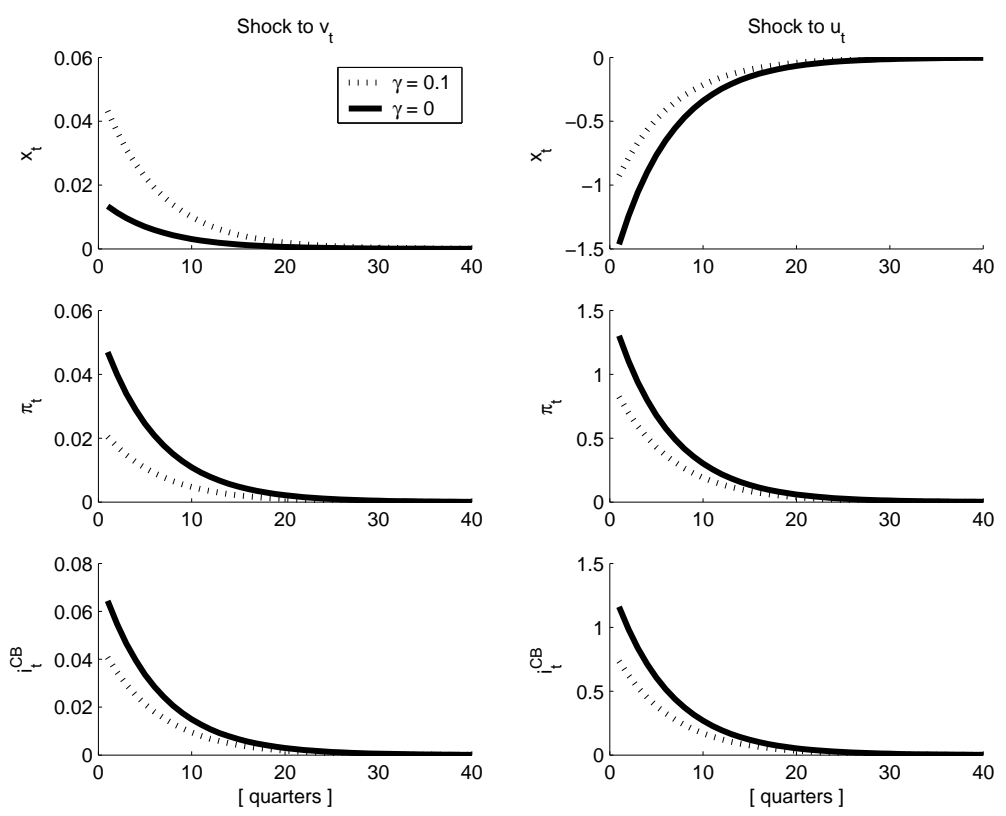

Figure 3: Impulse response functions when the credit channel is opened $(\gamma=0.1)$ and closed $(\gamma=0)$.

The economy with the credit channel opened is less responsive to the exogenous shocks than the economy where the channel is closed. The only exception is the response of output gap to the technology shock, which is about as twice as big in 
contrast to the no-credit market economy. Surprisingly, the credit channel does not affect the persistence of any model variable. Indeed, this holds only ceteris paribus. A detailed investigation on the model properties we leave for future research.

Table 3: Moments, correlation, and autocorrelation of simulated variables

\begin{tabular}{|c|c|c|c|c|c|c|c|c|c|c|}
\hline & \multirow[b]{2}{*}{ Mean } & \multirow[b]{2}{*}{ Std } & \multicolumn{3}{|c|}{ Correlation } & \multicolumn{5}{|c|}{ Autocorrelation (lag) } \\
\hline & & & $x$ & $\pi$ & $i_{t}^{C B}$ & 1 & 2 & 3 & 4 & 5 \\
\hline $\begin{array}{l}\gamma=0 \\
\operatorname{std}(x)\end{array}$ & 0 & 1.77 & 1 & -0.99 & -0.99 & 0.85 & 0.72 & 0.62 & 0.53 & 0.44 \\
\hline $\operatorname{std}(\pi)$ & 0 & 1.56 & & 1 & 0.99 & 0.85 & 0.72 & 0.62 & 0.53 & 0.44 \\
\hline $\operatorname{std}(i)$ & 0 & 1.39 & & & 1 & 0.84 & 0.72 & 0.62 & 0.52 & 0.44 \\
\hline $\begin{array}{c}\gamma=0.1 \\
\operatorname{std}(x)\end{array}$ & 0 & 2.79 & 1 & -0.99 & -0.98 & 0.85 & 0.72 & 0.61 & 0.52 & 0.44 \\
\hline $\operatorname{std}(\pi)$ & 0 & 2.47 & & 1 & 0.99 & 0.84 & 0.73 & 0.62 & 0.52 & 0.44 \\
\hline $\operatorname{std}(i)$ & 0 & 2.21 & & & 1 & 0.85 & 0.73 & 0.62 & 0.53 & 0.44 \\
\hline
\end{tabular}

\section{Imperfect Knowledge Experiment Results (details)}

In Figures 4 - 11 below, we present detailed simulation results on inflation, output gap, interest rate variability and mean-square forecast errors $(M S F E)$ of private agents and central bank. The results are obtained for time series of 100 observations and 500 experiments. The summary results presented in the paper are based on these simulations. One observation follows immediately, there is no monotone

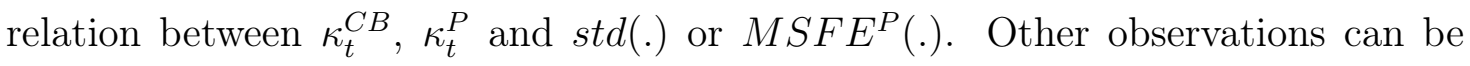
summarized as:

1. The policy parameter combination $\{1.5,0.4\}$ appears to be the most effective in delivering the lowest variation in inflation and output gap, although for some combinations of $\left\{\kappa^{C B}, \kappa^{P}\right\}$ a higher value of $\theta_{\pi}$ may deliver better results. These cases are marginal though.

2. The policy parameter combination $\{1.5,0.4\}$ appears to help the forecast efficiency. Both private agents and central bank form better forecast under 
that policy configuration.
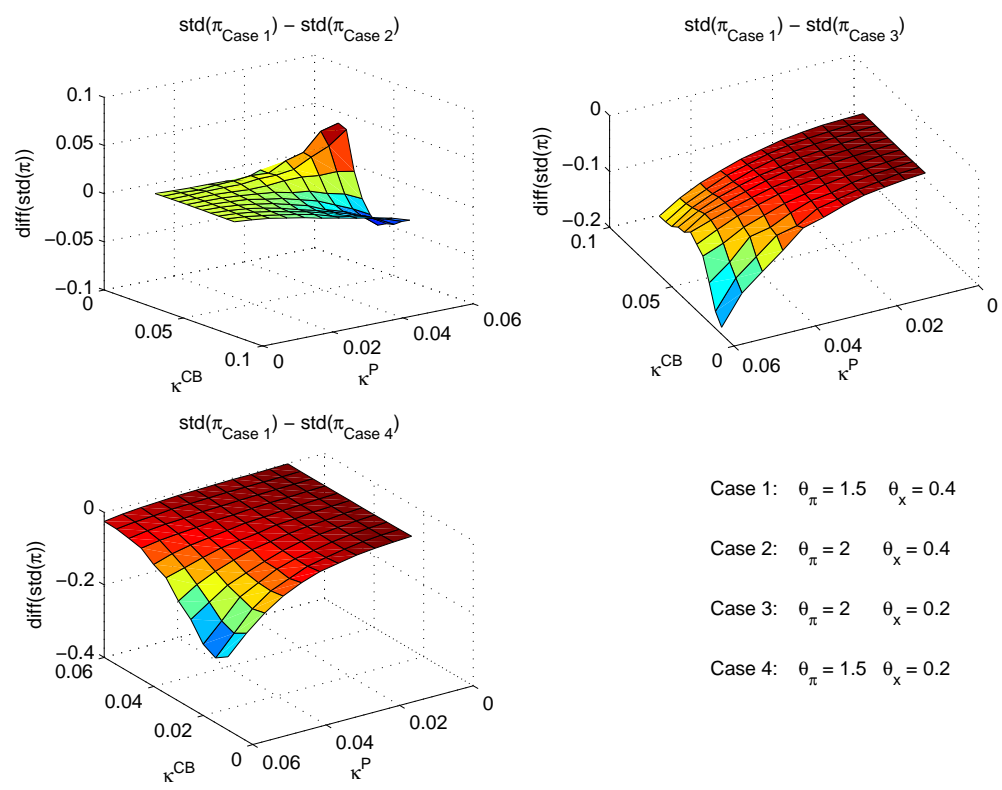

Case 1: $\theta_{\pi}=1.5 \quad \theta_{x}=0.4$

Case 2: $\quad \theta_{\pi}=2 \quad \theta_{\mathrm{x}}=0.4$

Case 3: $\quad \theta_{\pi}=2 \quad \theta_{x}=0.2$

Case 4: $\theta_{\pi}=1.5 \quad \theta_{x}=0.2$

Figure 4:
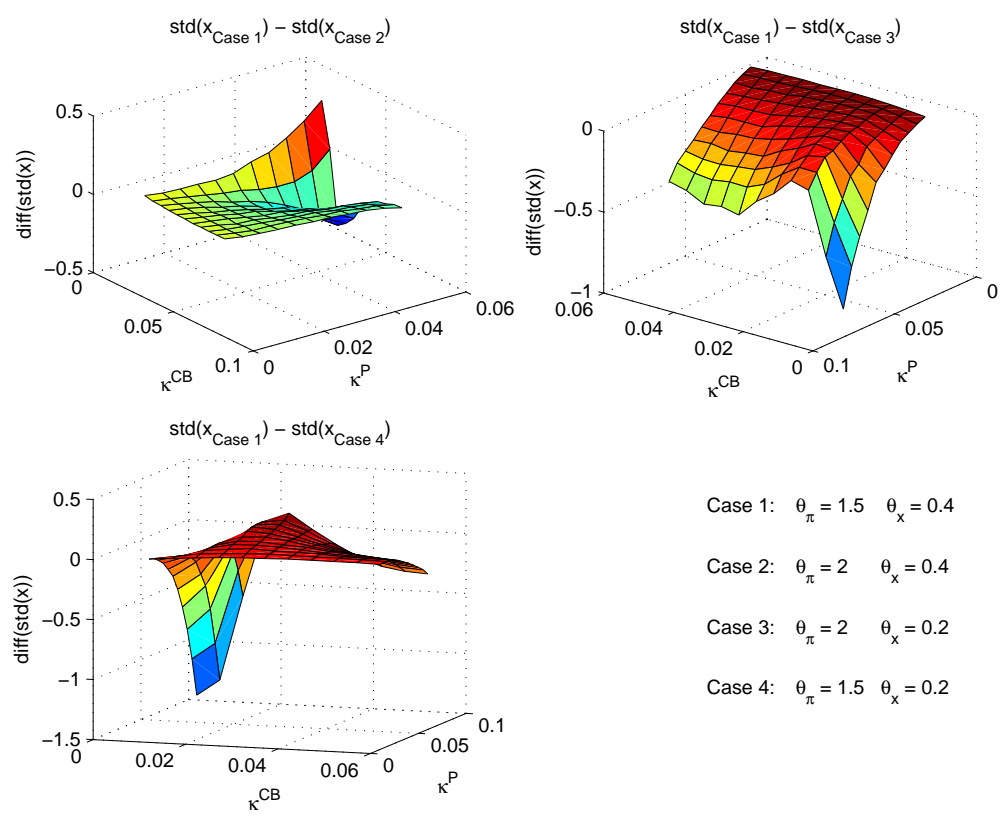

Case 1: $\theta_{\pi}=1.5 \quad \theta_{x}=0.4$

Case 2: $\quad \theta_{\pi}=2 \quad \theta_{x}=0.4$

Case 3: $\theta_{\pi}=2 \quad \theta_{\mathrm{x}}=0.2$

Case 4: $\theta_{\pi}=1.5 \quad \theta_{x}=0.2$

Figure 5: 

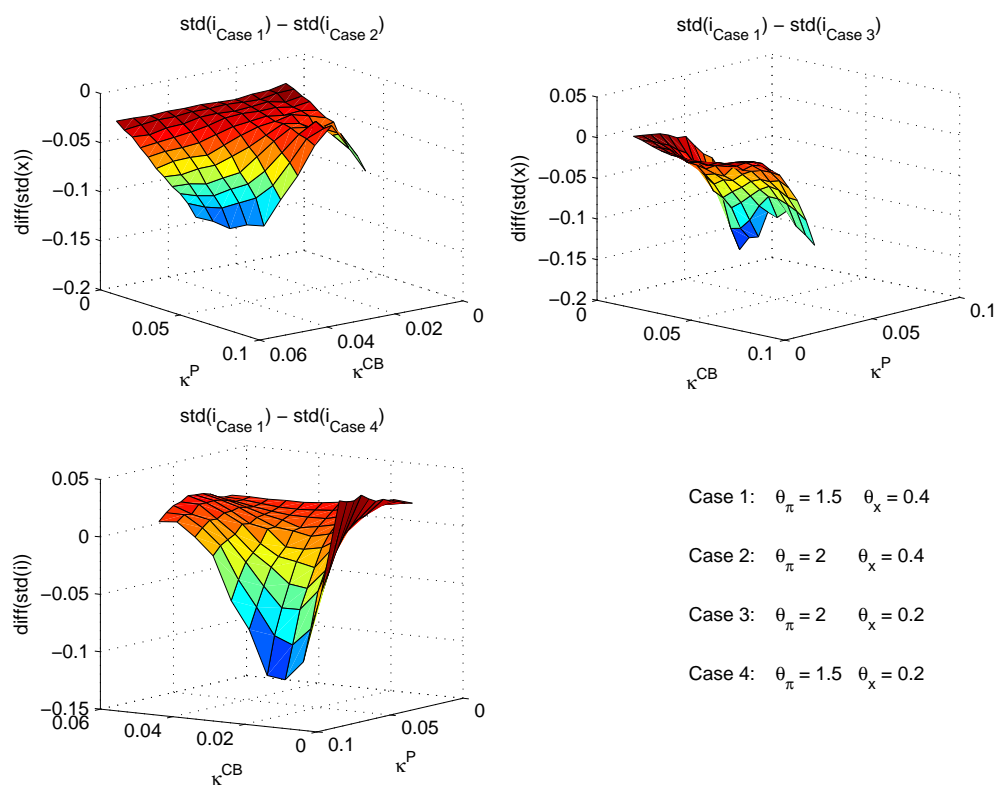

Figure 6:
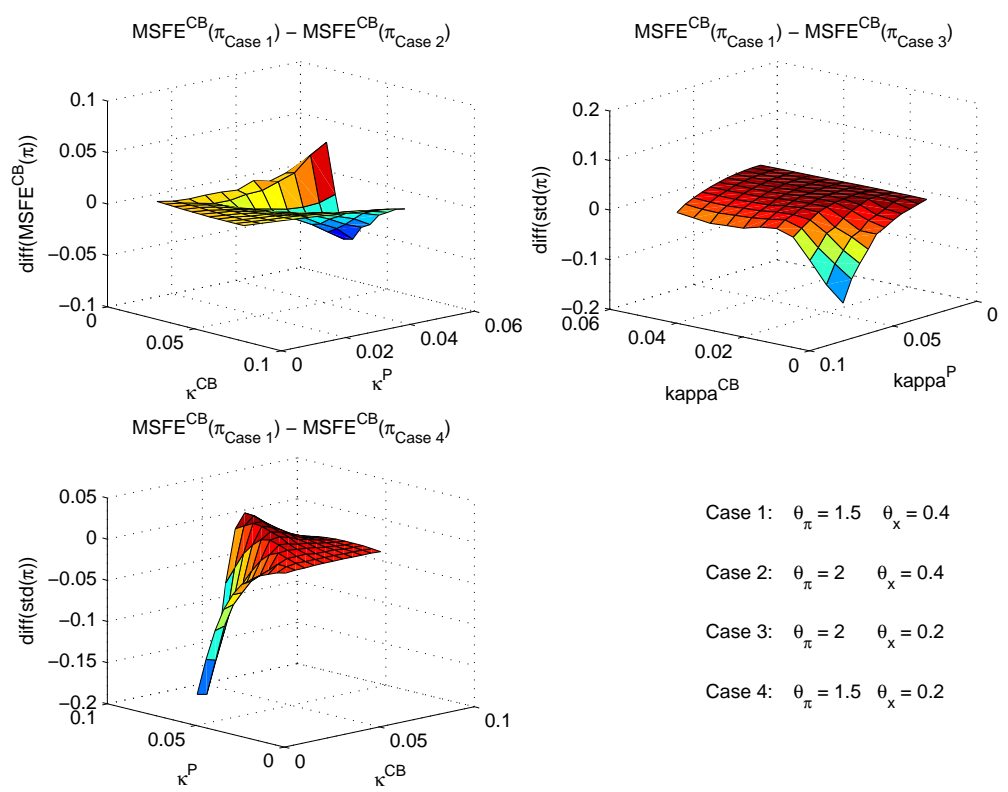

Case 1: $\theta_{\pi}=1.5 \quad \theta_{\mathrm{x}}=0.4$

Case 2: $\quad \theta_{\pi}=2 \quad \theta_{x}=0.4$

Case 3: $\theta_{\pi}=2 \quad \theta_{x}=0.2$

Case 4: $\theta_{\pi}=1.5 \quad \theta_{x}=0.2$

Figure 7: 

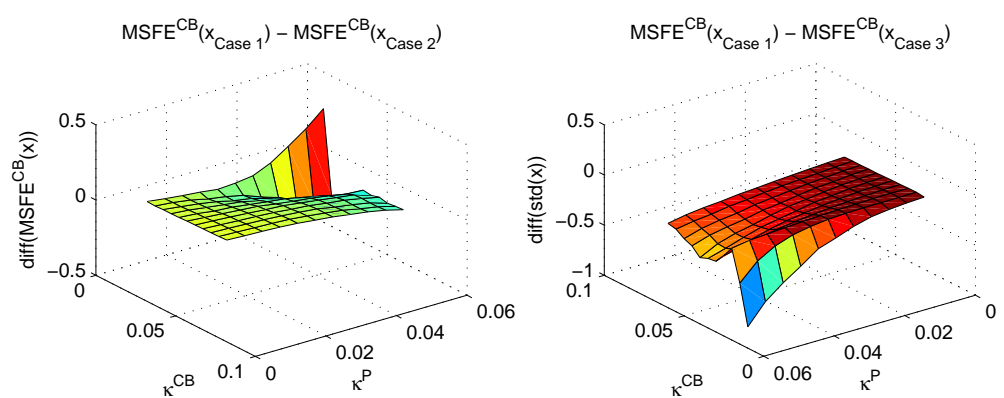

$\operatorname{MSFE}^{\mathrm{CB}}\left(\mathrm{x}_{\text {Case } 1}\right)-\mathrm{MSFE}^{\mathrm{CB}}\left(\mathrm{x}_{\text {Case }}{ }\right)$

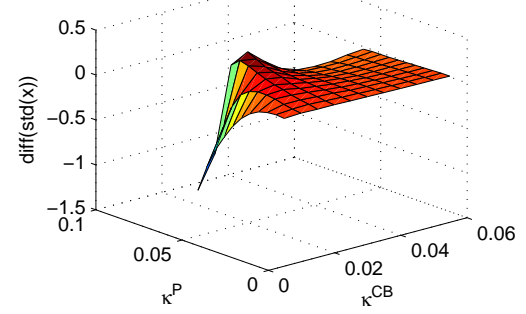

Case 1: $\quad \theta_{\pi}=1.5 \quad \theta_{x}=0.4$

Case 2: $\quad \theta_{\pi}=2 \quad \theta_{x}=0.4$

Case 3: $\quad \theta_{\pi}=2 \quad \theta_{x}=0.2$

Case 4: $\theta_{\pi}=1.5 \quad \theta_{\mathrm{x}}=0.2$

Figure 8:
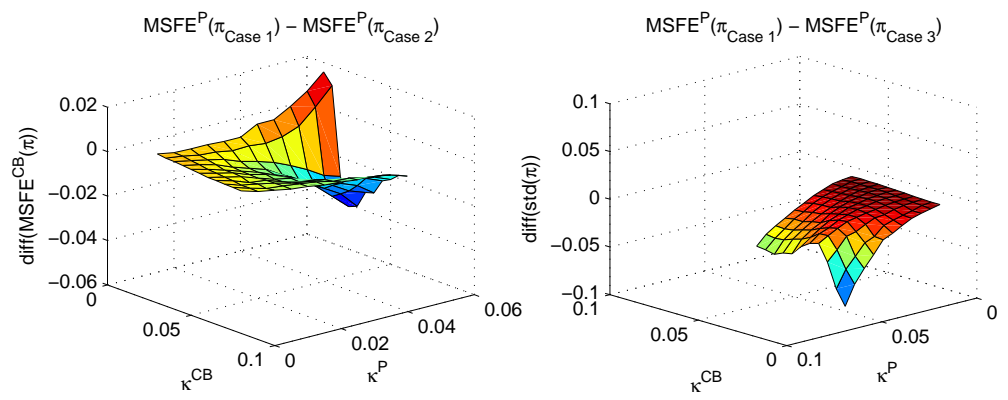

$\operatorname{MSFE}^{\mathrm{P}}\left(\pi_{\text {Case } 1}\right)-\operatorname{MSFE}^{\mathrm{P}}\left(\pi_{\text {Case } 4}\right)$

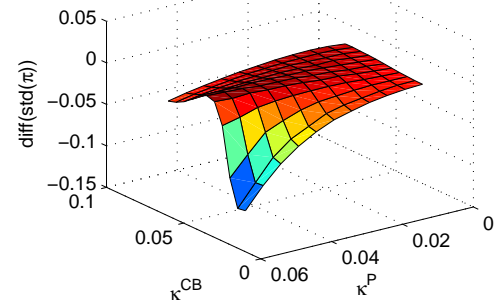

Case 1: $\theta_{\pi}=1.5 \quad \theta_{\mathrm{x}}=0.4$

Case 2: $\quad \theta_{\pi}=2 \quad \theta_{\mathrm{x}}=0.4$

Case 3: $\quad \theta_{\pi}=2 \quad \theta_{x}=0.2$

Case 4: $\theta_{\pi}=1.5 \quad \theta_{x}=0.2$

Figure 9: 


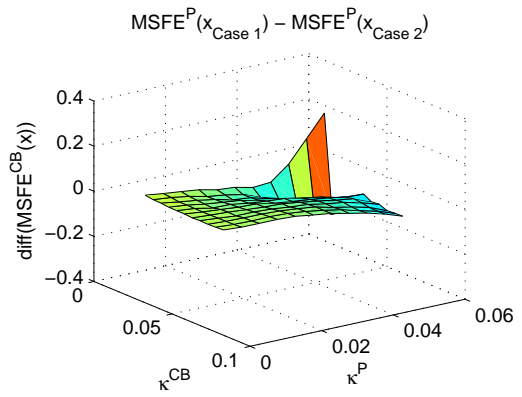

$\left.\operatorname{MSFE}^{\mathrm{P}}\left(\mathrm{x}_{\text {Case }}\right)-\mathrm{MSFE}^{\mathrm{P}}\left(\mathrm{x}_{\text {Case }}\right)\right)$
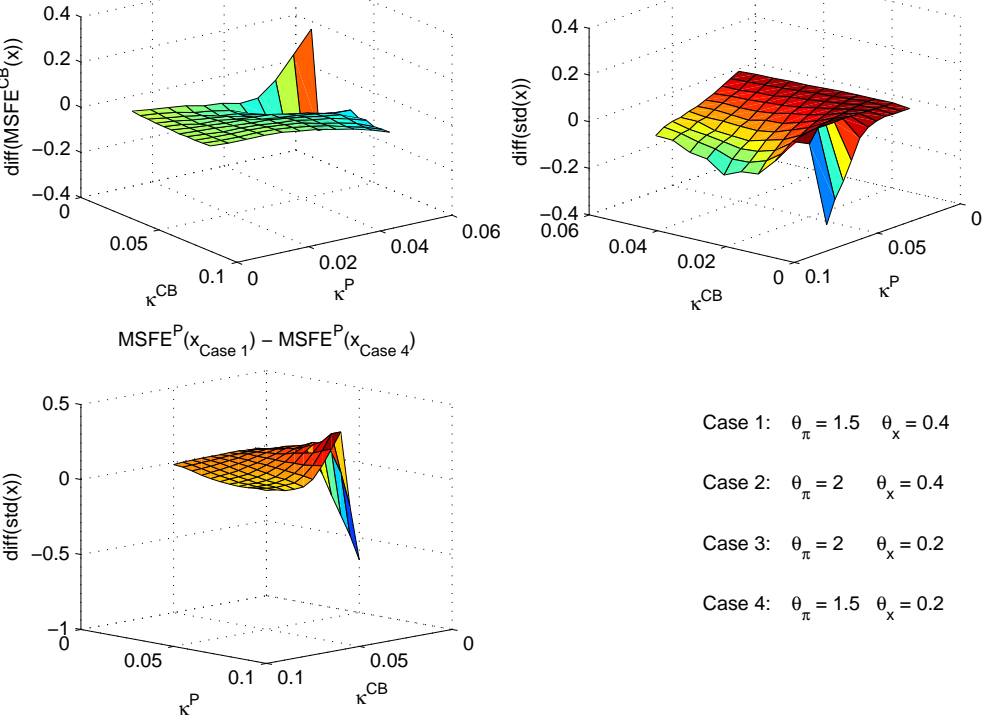

Case 1: $\theta_{\pi}=1.5 \quad \theta_{x}=0.4$

Case 2: $\quad \theta_{\pi}=2 \quad \theta_{x}=0.4$

Case 3: $\theta_{\pi}=2 \quad \theta_{x}=0.2$

Case 4: $\theta_{\pi}=1.5 \quad \theta_{x}=0.2$

Figure 10:

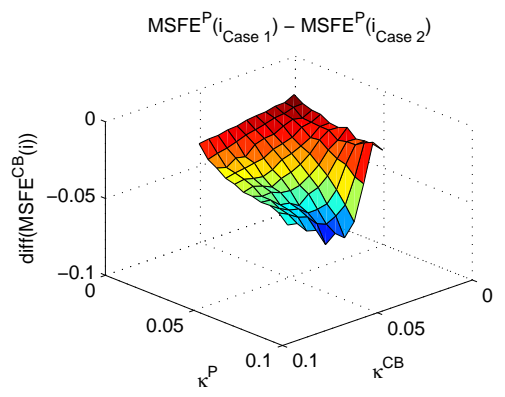

$\operatorname{MSFE}^{\mathrm{P}}\left(\mathrm{i}_{\text {Case } 1}\right)-\operatorname{MSFE}^{\mathrm{P}}\left(\mathrm{i}_{\text {Case } 3}\right)$

$\operatorname{MSFE}^{\mathrm{P}}\left(\mathrm{i}_{\text {Case }} 1\right)-\operatorname{MSFE}^{\mathrm{P}}\left(\mathrm{i}_{\text {Case } 4}\right)$
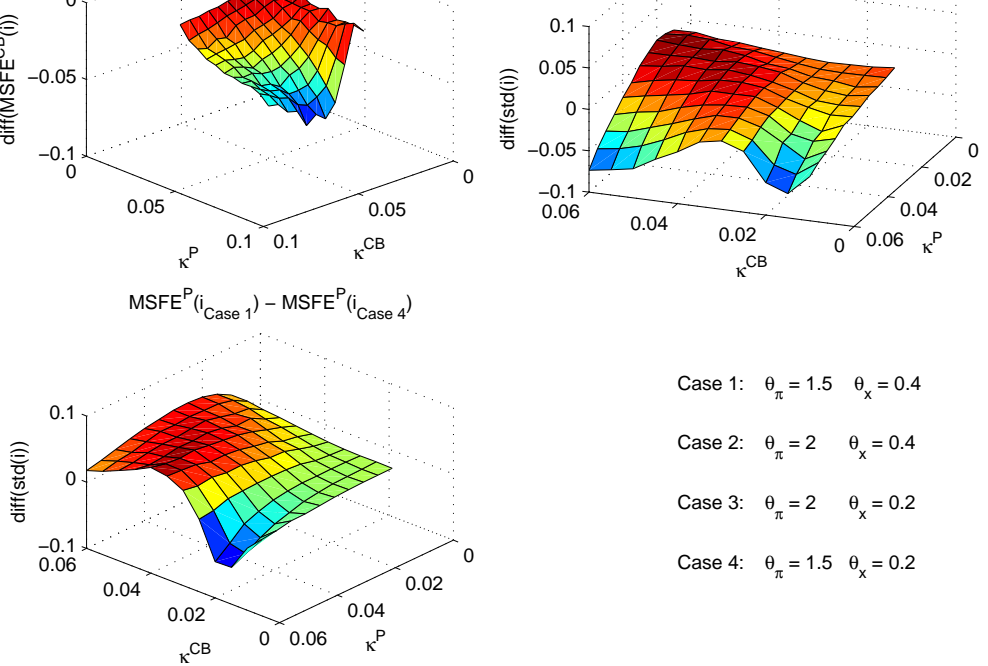

Figure 11:

Case 1: $\quad \theta_{\pi}=1.5 \quad \theta_{\mathrm{x}}=0.4$

Case 2: $\quad \theta_{\pi}=2 \quad \theta_{\mathrm{x}}=0.4$

Case 3: $\quad \theta_{\pi}=2 \quad \theta_{x}=0.2$

Case 4: $\theta_{\pi}=1.5 \quad \theta_{x}=0.2$ 
Individual researchers, as well as the on-line and printed versions of the CERGE-EI Working Papers (including their dissemination) were supported from the following institutional grants:

- Center of Advanced Political Economy Research [Centrum pro pokročilá politicko-ekonomická studia], No. LC542, (2005-2009),

- Economic Aspects of EU and EMU Entry [Ekonomické aspekty vstupu do Evropské unie a Evropské měnové unie], No. AVOZ70850503, (2005-2010);

- Economic Impact of European Integration on the Czech Republic [Ekonomické dopady evropské integrace na ČR], No. MSM0021620846, (2005-2011);

Specific research support and/or other grants the researchers/publications benefited from are acknowledged at the beginning of the Paper.

(c) Martin Fukač, 2005

All rights reserved. No part of this publication may be reproduced, stored in a retrieval system or transmitted in any form or by any means, electronic, mechanical or photocopying, recording, or otherwise without the prior permission of the publisher.

Published by

Charles University in Prague, Center for Economic Research and Graduate Education (CERGE) and

Economics Institute (EI), Academy of Sciences of the Czech Republic

CERGE-El, Politických vězňů 7, 11121 Prague 1, tel.: +420 224005 153, Czech Republic.

Printed by CERGE-EI, Prague

Subscription: CERGE-EI homepage: http://www.cerge-ei.cz

Editors: Directors of CERGE and EI

Managing editors: Deputy Directors for Research of CERGE and EI

ISSN 1211-3298

ISBN 80-7343-071-1 (Univerzita Karlova v Praze, CERGE)

ISBN 80-7344-060-1 (Národohospodářský ústav AV ČR, Praha) 
CERGE-EI

P.O.BOX 882

Politických vězňů 7

11121 Praha 1

Czech Republic http://www.cerge-ei.cz 